\title{
Political leader survival: does competence matter?
}

\author{
Shu Yu' $\mathbf{u}^{1}$ Richard Jong-A-Pin ${ }^{2}$
}

Received: 20 July 2014/ Accepted: 4 February 2016/Published online: 18 February 2016

(C) The Author(s) 2016. This article is published with open access at Springerlink.com

\begin{abstract}
We examine whether economic and military competence of political leaders affect their duration in office. We introduce leader heterogeneity in the selectorate theory of Bueno de Mesquita et al. (2003) and derive the hypothesis that in the presence of a revolutionary threat, economic competence is negatively related to political survival, but that the effect is moderated by the size of the winning coalition. As military and economic competence are negatively correlated, the opposite holds for military competence. We present empirical estimates using proxies for military and economic competence in a parametric Weibull duration model that support our theoretical predictions.
\end{abstract}

Keywords Political leader - Survival analysis - Leader competence - Selectorate theory

JEL Classification $\quad$ D020 $\cdot$ D720 $\cdot$ D740 $\cdot$ O120

\section{Introduction}

Even though almost all political leaders enter office with the aim of maximizing tenure, we observe wide variety in actual tenure throughout the world. Whereas King Sobuhza II of Swaziland stayed in power for 62 years, many leaders do not stay in power for more than a few years. The variation in tenure of political leaders across and within countries has led to research focusing on their political survival. Taking the political leader as the unit of

Richard Jong-A-Pin

r.m.jong.a.pin@rug.nl

Shu Yu

syu26@ur.rochester.edu

1 Skanly Center, University of Rochester, 101 Harkness Hall, Rochester, NY 14627-0147, USA

2 Faculty of Economics and Business, University of Groningen, Nettelbosje 2, 9747 AE Groningen, The Netherlands 
analysis, these studies mainly have focused on political, institutional, and economic variables to explain office length. ${ }^{1}$

Political leaders can maximize their time in office in different ways. They can increase the welfare of all citizens or may choose only to assure the welfare of a small elite to safeguard their position. Political leaders can also stay in power through repression. In this paper, we examine how the competence levels of political leaders with respect to welfare maximization and repression influence their political survival. We study this relation both theoretically and empirically.

We develop a model, which is based on the selectorate theory of Bueno de Mesquita et al. (2003), but has the novel feature that it allows for heterogeneous leaders. We evaluate the implications of the trade-off between economic and military competence by studying the interaction between the winning coalition, i.e., the group of elites who can prioritize its leader choice, and the opposition, i.e., the majority of citizens, that can initiate a revolution. In our model, we incorporate the finding of Besley et al. (2011) that better educated leaders are economically more competent and generate more output that is allocated to public goods and private rents. More economically competent leaders seem to appeal to both the elite and the opposition. However, economic competence comes at the cost of military competence. The latter is important, as military competence is required to fend off revolutionary attempts and to safeguard the position of the current elite and their access to rents.

From our model, we derive the hypothesis that even though the members of the winning coalition obtain more private rents from an economically competent leader, they will favor one with more military experience when the size of the winning coalition is small. The reason is that the risk of losing coalition membership outweighs the immediate benefit of economic prosperity under a more economically competent leader. As private rents need to be shared among the winning coalition members, a small coalition implies that, ceteris paribus, fewer rents have to be shared and therefore increases the value of having a more military competent leader. On the other hand, when winning coalitions are large, public goods become relatively more important and coalition members are more likely to favor an economically competent political leader.

We find empirical support for our hypothesis when we add proxies for economic and military competence to the empirical models as used by Bueno de Mesquita and Smith (2010). That is, we estimate a parametric Weibull duration model on a sample of more than a 1000 political leaders for the period 1875-2004. Our samples focus on autocratic political leaders and leaders confronted with political uprising. The results are robust to alternative model specifications, different subsamples, and measures of economic competence.

By introducing leader heterogeneity into the selectorate theory, we bridge the gap between the empirical literature emphasizing the relevance of leader characteristics for economic and political outcomes, and the theoretical framework offered by the selectorate theory to study leader survival. Connecting these strands of the literature teaches us that political regimes facing the threat of revolution do not only select leaders of low economic competence (Besley and Reynal-Querol 2011), but the impact of competent leaders is also constrained as office duration is likely to be short. As such, weak polities find themselves in a poverty trap because the ruling elite will always prefer a strong military leader above an economically competent one.

\footnotetext{
1 See, e.g., Bueno de Mesquita and Smith (2010); Bueno de Mesquita and Siverson (1995); Przeworski and Gandhi (2007); Cuaresma et al. (2011) and Holcombe and Boudreaux (2013).
} 
The remainder of the paper is structured as follows. In Sect. 2 we derive our hypothesis on the basis of our theoretical model. Section 3 discusses our data and the duration framework employed in our empirical analysis. In Sect. 4 the estimation results are presented. In Sect. 5 present several robustness analyses. In Sect. 6, we reflect on our findings and conclude.

\section{Theoretical model}

We set up a formal model in which the winning coalition chooses a political leader in the presence of a revolution threat from the opposition. Our model is based on the selectorate theory of Bueno de Mesquita et al. (2003). We take a setting similar to their model to build a one-shot static model. ${ }^{2}$ After introducing the main concepts and the players in the model, we continue to describe the timeline of the game and discuss the expected utility function of each player. Then we describe the equilibrium and how the incumbent's competence level influences his survival rate. Finally, we derive the main hypothesis that we test in Sect. 3 .

\subsection{The main concepts}

\subsubsection{The winning coalition and the opposition}

Consider a mass of residents of size 1 . A subset with political rights forms the selectorate $(\boldsymbol{S})$ with size, $s$, which ranges from 0 to 1 . Selectorate membership depends on a mix of characteristics such as birthplace, lineage and gender. ${ }^{3}$ Within the selectorate there is a group of residents, called the winning coalition $(\boldsymbol{W})$. It is the smallest group with political power to choose a leader. The size of the winning coalition is equal to $w, w \in[0, s]$. Here we assume $w$ and $s$ to be exogenously given and fixed in order to focus on the impact of leaders' personal characteristics on their survival and how it differs in different regime settings. ${ }^{4}$ The value of $w$ depends on the distribution of political power and resources such as arms, capital and abilities. In a military regime, $w$ depends relatively more on the distribution of arms and martial power, while it depends more on capital distribution in advanced democracies. $^{5}$

\footnotetext{
${ }^{2}$ In contrast to the original selectorate theory model, our model is a one-shot game, wherein the winning coalition faces the choice of replacing the incumbent with an unknown challenger. We model a one-shot game to focus on the effect of competence on political survival and to keep the model simple. Extending the model to two periods requires more structure, but does not change the result we derive in proposition 1 below.

${ }^{3}$ For instance, in the United States, women were denied voting rights until the passage of the Nineteenth Amendment to the United States Constitution in 1920. Thus, before that point, at least half of US residents was not included in the selectorate. For more details, see Bueno de Mesquita et al. (2003).

${ }^{4}$ Questions on how w and s are determined have been analyzed by Ray and Vohra (1999), Konishi and Ray (2003), Acemoglu et al. (2008), and others. These studies look at the dynamics in winning coalition formation. They analyze how institutions and the distribution of resources/political power affect the size and stability of coalitions. Instead of furthering research in this direction, we focus on how existing coalitions influence the selection of leaders.

${ }^{5}$ The sizes of the selectorate and the winning coalition are related to the concepts of de facto and de jure political powers, as discussed in Acemoglu and Robinson (2006). While de jure political power corresponds to the political rights granted by law, de facto political power originates from resources. We argue that the
} 
To clarify the concepts of $w$ and $s$, Bueno de Mesquita and Smith (2010) show that in a directly elected presidential system, $S$ amounts to all adults (i.e. $s=1$ ) and that support from half of the selectorate in such a system ensures political survival $\left(w=\frac{s}{2}\right)$. However, in a Westminster type of parliamentary system, the leader needs to secure the support of half of the people in half of the districts $\left(w=\frac{s}{4}\right)$. Military juntas or monarchies have much smaller selectorates and even smaller winning coalitions comprising by military elites or aristocrats. For example, in the former Soviet Union, only communist party members were part of the selectorate. Since party members accounted for less than $7 \%$ of the entire population (in the 1970s), the value of $s$ was close to zero. At the same time, the Politburo was in charge of selecting the political leader. Since the Politburo had only 14 full members, $w$ was even closer to zero. ${ }^{6}$

The mass of residents is divided into three disjoint sets: (1) residents that are not in the selectorate $(\overline{\boldsymbol{S}}),(2)$ residents that are in the selectorate but not in the winning coalition $(\overline{\boldsymbol{W}})$, and, finally, (3) residents that are in the winning coalition $(\boldsymbol{W})$. The corresponding representative members are $\bar{S}_{i}, \bar{W}_{i}$ and $W_{i}$ and these representative members take the respective group decisions. According to Bueno de Mesquita et al. (2003), to maximize his payoff, the incumbent would like to keep the winning coalition as small as possible and maintain the same set of coalition members. ${ }^{7}$ Since $\boldsymbol{W}$ is the smallest group with political power to select a leader, it follows that the joint political power of $\overline{\boldsymbol{W}}$ and $\overline{\boldsymbol{S}}$ is equivalent to the power of $\boldsymbol{W}$. The winning coalition and the opposition interact as follows: (1) the winning coalition selects the leader; (2) the opposition $(\overline{\boldsymbol{W}}$ and $\overline{\boldsymbol{S}})$ can reject the decision of the winning coalition and attempt a revolution; (3) a revolution attempt only occurs when both $\overline{\boldsymbol{W}}$ and $\overline{\boldsymbol{S}}$ find it beneficial; (4) a revolution threat only materializes into a revolution when the opposition solves the collective action problem and the incumbent is unable to dismantle and appease the opposition. The threshold for posing a revolutionary threat and the probability of having a revolution will be discussed in Sect. 2.3.

\subsubsection{The candidates}

The winning coalition chooses between two candidates: the incumbent $\left(C_{0}\right)$ and the challenger $\left(C_{1}\right)$. Candidates have two dimensions of competence: economic competence $\left(e_{j}, j=0,1\right)$, and military competence $\left(m_{j}\right)$. Economic competence determines the level of aggregate output (i.e. $Y=e_{j}$ ) and $e_{j}$ is uniformly distributed between 0 and 1 . Military competence determines the incumbent's ability to turn down a revolution, i.e. the incumbent can repress and dismantle the joint action to revolt from $\overline{\boldsymbol{W}}$ and $\overline{\boldsymbol{S}}$ with probability $m_{0}$.

Footnote 5 continued

size of the selectorate represents the de jure democracy level while the size of winning coalition represents the de facto democracy level.

6 See Bueno de Mesquita and Smith (2010) and Bueno de Mesquita et al. (2003) for more detailed explanations of these concepts and more examples.

7 The underlying reason is that in Bueno de Mesquita et al. (2003) model, the output is divided into public goods, private rents and payoffs to the incumbent. To maximize his payoff, the incumbent will minimize the private rents shared among the winning coalition. Therefore, he would like the size of the winning coalition to be just large enough to have the political power to select him at the equilibrium point. This implies that $\mathbf{W}=\bar{S}+\bar{W}$. However, that assumption is not essential to the results of our model. Since the revolution threshold of $\bar{W}$ is always higher than that of $\bar{S}$, whether to revolt or not is essentially determined by $\bar{W}$. 
When the incumbent is in office, his economic competence is publicly observed through the economic performance of the country. However, his military competence is not directly observed. It is only revealed once he has to act upon an attempt. However, residents can form an expectation about the incumbent's military competence, i.e., $E\left(m_{0}\right)$. We assume here that $m_{j}$ is negatively correlated with $e_{j}: E\left(m_{j}\right)=1-\alpha e_{j}{ }^{8}$ where $\alpha(\alpha \in[0,1])$ is a known constant and indicates the correlation between $e_{j}$ and $m_{j} .{ }^{9}$

While the incumbent is known at the start of the game, the challenger is unknown. He will be drawn randomly from the candidate pool after the winning coalition proposes its leader of choice. The candidate pool includes candidates whose individual economic competencies follows a uniform distribution between 0 and 1 (i.e., $e_{j} \sim U[0,1]$ ). The challenger's economic competence is assumed to be revealed to the residents after the winning coalition has made their leader choice.

Finally, in line with the selectorate theory, we assume that each candidate has a specific winning coalition. The composition of the candidate-specific coalition is observed only after the candidate assumes power. This implies that staying with the incumbent means no change in the political setup. Furthermore, a peaceful transition to the challenger gives each selectorate member a probability of $\frac{w}{s}$ of being in the new coalition.

\subsubsection{Public goods and private rents}

The level of aggregate output, determined by the leader's economic competence, is divided into public goods and private rents. ${ }^{10}$ A fixed fraction $(x \in(0,1))$ of aggregate output goes to private rents (denoted as $\mathrm{z}_{j}$ ) while a fraction $1-\mathrm{x}$ of aggregate output is used to produce public goods (denoted as $\mathrm{g}_{j}$ ). ${ }^{11}$ Public goods are accessible to every selectorate member, whereas private rents are shared equally by the winning coalition's members. For simplicity, we assume that public goods are produced according to a one-for-one production

\footnotetext{
${ }^{8}$ Candidates' true military competence equals $m_{j}=1-\alpha e_{j}+\epsilon$, where $\varepsilon$, follows a normal distribution $\mathrm{N}$ $(0,1)$. It accounts for the possibility that the opposition misjudges a leader's military competence.

9 The assumption that leaders' competence levels are negatively correlated is strongly supported by our data, which will be described in detail in Sect. 3. One explanation for this negative association is that it takes time to develop competence in either dimension. As time is scarce, other competences cannot be developed sufficiently. For example, if the candidate has spent a long time serving in the military, then he would not have had time to go to university.

${ }^{10}$ Bueno de Mesquita and Smith (2010) assume that the leader can retain the difference between government revenue and the sum of public goods and private rents. They use this difference to measure leader survival. Here we take a different approach and assume that the incumbent does not know exactly the functional form determining his survival rate (which is decided by the winning coalition). He only knows that his survival rate is a function that is strictly increasing in the extra benefits he can bring to the winning coalition relative to the challenger. Therefore, in equilibrium, the incumbent will not keep any rents for himself, but distributes aggregate output over public goods and private rents. This approach allows us to focus on the impact of $e_{0}$ in our analysis. To measure political survival we will focus on the difference between the expected utility that a winning coalition member will have under the incumbent and the (unknown) challenger.

11 In Bueno de Mesquita et al. (2003), the loyalty norm, i.e., the ratio of the size of winning coalition over the size of the selectorate, is fixed. They show that it is optimal for the incumbent to choose the same set and size of his winning coalition. We follow their approach and take the size of the selectorate (s) and the size of the winning coalition (w) as given. Moreover, we also take $\mathrm{x}$ as given. The reason is that $\mathrm{x}$ can be considered as a measure of income inequality, which hardly changes in the short-run. See Bueno de Mesquita et al. (2003) for details.
} 
technology, with 1 unit of input producing 1 unit of public goods. ${ }^{12}$ Thus, each selectorate member receives $\mathrm{e}_{j}(1-x)$ of public goods and private rents equal to $\mathrm{e}_{j} \frac{x}{w}$. Since a winning coalition member receives both public goods and private rents, he has the following payoff function:

$$
U^{w}=\mathrm{z}_{j}+\mathrm{g}_{j}=\mathrm{e}_{j}(1-x)+\mathrm{e}_{j} \frac{x}{w}, \quad \text { for } j \in\{0,1\}
$$

Furthermore, a selectorate member who is not a coalition member $\left(\bar{W}_{i}\right)$ has access only to public goods, whereas residents who are not in the selectorate $\left(\bar{S}_{i}\right)$ have access neither to public goods nor private rents:

$$
\begin{gathered}
U^{\bar{w}}=\mathrm{z}_{j}=\mathrm{e}_{j}(1-x), \quad \text { for } j \in\{0,1\} \\
U^{\bar{s}}=0, \quad \text { for } j \in\{0,1\} .
\end{gathered}
$$

\subsection{Timeline}

Figure 1 visualizes the timeline of our one-shot static game. In words, it works as follows:

1. The incumbent is in power and his economic competence, $\mathrm{e}_{0}$, is publicly observed.

2. The winning coalition proposes the incumbent or an unknown challenger (that will be drawn by nature in the step 3 ).

3. Nature draws the (so far unknown) challenger and his economic competence, $e_{1}$, is revealed.

4a. If the challenger is proposed, the opposition has two options, i.e., either to accept the challenger or to pay a small cost, $\tau$, to reject the challenger and keep the incumbent. ${ }^{13}$ In either case, $\bar{S}_{i}$ remains disenfranchised.

4b. If the incumbent is proposed, the opposition decides whether to launch a revolution, which destroys part $(k)$ of aggregate output:

i. If the revolution condition is fulfilled and the incumbent cannot dismantle it, a revolution succeeds with probability $\left(1-E\left(m_{1}\right)\right)$ and the challenger comes into power. The challenger democratizes the state by setting $\mathrm{s}$ to 1 , $\mathrm{w}$ to its possible maximum, and abolishes private rents, i.e., $\mathrm{z}_{\mathrm{j}}=0 .{ }^{14}$

ii. If no revolution occurs, the incumbent stays in power. He will keep the regime settings constant and the sitting winning coalition remains.

5. The (new) leader comes into power and payoffs are realized.

\footnotetext{
12 Assuming different production costs for public goods does not change our results. A detailed proof is available upon request.

${ }^{13}$ We assume that the opposition needs to bear a rejection cost when the winning coalition proposes the challenger. Since the winning coalition is ruling the regime, the opposition needs to engage in certain activities such as lobbying, riots, or strikes, to reject the winning coalition's proposal.

14 Since the incumbent represents the status quo, he will not democratize the state. Furthermore, political structures (i.e., $s$ and $w$ ) often remain the same after a successful revolution. Our results are not sensitive to this assumption. Detailed proof is shown in the Appendix, which can be found at http://www.rug.nl/staff/r. m.jong.a.pin/ and is available on request.
} 


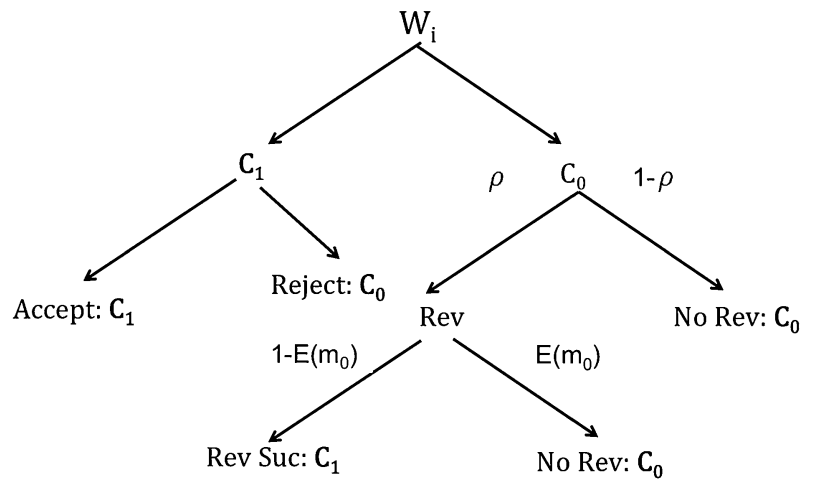

Fig. 1 Game tree

\subsection{The equilibrium}

The challenger can come into power in two ways: (1) peacefully, i.e., being proposed by the winning coalition, which will be followed by a reallocation of the citizens over the winning coalition and the rest of the selectorate, or (2) violently, i.e., not being proposed by the coalition but supported by the opposition in a revolution. Such a revolution, however, will destroy part $(k)$ of aggregate output.

In the following section, we use backward induction and describe the sub-game perfect Nash equilibrium. We start with the subgame wherein the challenger is proposed and illustrate the best response of the opposition. Then we show under which conditions the opposition will attempt a revolution. Finally, we show how the incumbent's economic competence level influences decision-making of the winning coalition when confronted with a revolutionary threat.

\subsubsection{When the challenger is proposed}

If the winning coalition proposes the challenger, the opposition has two options, i.e., either to accept the challenger or to pay a small $\operatorname{cost}, \tau$, to reject the challenger and keep the incumbent. ${ }^{15} \bar{S}_{i}$ is always better off by choosing the challenger. The reason is as follows: After a peaceful leadership change, the winning coalition and the rest of the selectorate will be reshuffled, but $\bar{S}_{i}$ remains the same. Therefore, if $\bar{S}_{i}$ accepts the challenger, no costs or gains are incurred $\left(E U^{\bar{S}_{i}}\left(C_{1}, C_{1}\right)=0\right)$. However, if the incumbent is chosen, $\bar{S}_{i}$ will remain disenfranchised but pays a rejection cost, i.e., $E U^{\bar{S}_{i}}\left(C_{0}, C_{1}\right)=-\tau$. Since $E U^{\overline{S_{i}}}\left(C_{0}, C_{1}\right)<E U^{\bar{S}_{i}}\left(C_{1}, C_{1}\right), \bar{S}_{i}$ 's best response is to accept the challenger when he is proposed.

Since $\bar{S}_{i}$ will not revolt, $\bar{W}_{i}$ will not revolt either, because a revolution can be initiated only when $\bar{S}_{i}$ and $\bar{W}_{i}$ join forces. Hence, proposing the challenger always implies peaceful leadership change.

\footnotetext{
${ }^{15}$ We assume that the opposition needs to bear a rejection cost when the winning coalition proposes the challenger. Since the winning coalition is the ruling party in the regime, the opposition need to engage in certain activities, e.g., lobbying, riots, or strikes, to reject the winning coalition's proposal.
} 
Proposition 1 When the winning coalition proposes the challenger, the opposition always accepts the challenger as the next leader.

\subsubsection{Revolution threshold when the incumbent is proposed}

When the challenger is not proposed by the winning coalition and the opposition jointly attempts a revolution, two scenarios could follow. First, if the incumbent rebuffs the attempted uprising, then the opposition is forced to accept him. This happens with probability $m_{1}$. Second, if the revolutionary attempt succeeds, then it costs $k$ per resident and the challenger democratizes the regime, i.e., he will set $s$ to $1, w$ to its possible maximum, and $\mathrm{z}_{j}$ to $0 .{ }^{16}$

We make the assumption of democratization here (like Bueno de Mesquita and Smith 2009) since in most cases revolutionaries are motivated by the promise of democratization. However, political structures (i.e., $s$ and $w$ ) sometimes would remain the same after a successful revolution. Our results also hold for cases where no political structural changes occur after a revolution succeeds. ${ }^{17}$

Here we show the condition required by $\bar{S}_{i}$ to revolt, and then the condition required by $\bar{W}_{i}$. Finally we demonstrate the revolution threshold imposed by $\bar{S}_{i}$ and $\bar{W}_{i}$ jointly and show the probability of having a revolution if the winning coalition proposes the incumbent, i.e., $\rho$.

1. $\bar{S}_{i}$ revolts if $E U^{\bar{S}_{i}}\left(C_{1}, C_{0}\right)>E U^{\bar{S}_{i}}\left(C_{0}, C_{0}\right)$

The opposition takes into account how likely it is that a revolution attempt will be dismantled and how costly it will be. For the residents outside the selectorate, $\bar{S}_{i}$, the following payoff is realized if they revolt:

$$
E U^{\bar{S}_{i}}\left(C_{1}, C_{0}\right)=\left(1-E\left(m_{0}\right)\right)\left(e_{1}-k\right)+E\left(m_{0}\right) * 0=\left(1-E\left(m_{0}\right)\right)\left(e_{1}-k\right) .
$$

If $\bar{S}_{i}$ revolts successfully, the challenger will come into power, democratize the regime, and deliver aggregate output $\mathrm{e}_{1}$. However, this only happens with probability $1-E\left(m_{1}\right)$ and costs k. If $\bar{S}_{i}$ cannot revolt successfully, they will receive zero since they then have neither access to private rents nor to public goods. The same applies when the incumbent decides not to revolt, i.e., $E U^{\bar{S}_{i}}\left(C_{0}, C_{0}\right)=0$. Therefore, $\bar{S}_{i}$ revolts when $e_{1}>k$, i.e., when the challenger can provide agwill come into power with probabilitygregate output that is larger than the revolution's cost.

2. $\overline{\mathrm{W}}_{\mathrm{i}}$ revolts if $\mathrm{EU}^{\overline{\mathrm{W}}_{\mathrm{i}}}\left(\mathrm{C}_{1}, \mathrm{C}_{0}\right)>\mathrm{EU}^{\overline{\mathrm{W}}_{\mathrm{i}}}\left(\mathrm{C}_{0}, \mathrm{C}_{0}\right)$

If $\overline{\mathrm{W}}_{\mathrm{i}}$ revolts, the challenger will come into power with probability $1-E\left(m_{0}\right)$. If so, $\overline{\mathrm{W}}_{\mathrm{i}}$ receives $e_{1}$ and pays revolution cost, $k$. If the revolution is dismantled, $\overline{\mathrm{W}}_{\mathrm{i}}$ will receive his current payoff, i.e., the public goods provided by the incumbent, $e_{0}(1-x)$. Therefore, the expected utility for $\overline{\mathrm{W}}_{\mathrm{i}}$ to revolt is:

$$
E U^{\bar{W}_{i}}\left(C_{1}, C_{0}\right)=\left(1-E\left(m_{0}\right)\right)\left(e_{1}-k\right)+E\left(m_{0}\right) e_{0}(1-x)
$$

If $\overline{\mathrm{W}}_{\mathrm{i}}$ does not revolt, it will receive the public goods provided by the incumbent, i.e., $\mathrm{EU}^{\overline{\mathrm{W}}_{i}}\left(\mathrm{C}_{0}, \mathrm{C}_{0}\right)=e_{0}(1-x)$. Therefore, it is beneficial for $\overline{\mathrm{W}}_{\mathrm{i}}$ to revolt when

\footnotetext{
16 Since the incumbent represents the status quo, he will not democratize the state.

17 A detailed proof is shown in the Appendix.
} 
$e_{1}>k+e_{0}(1-x)$. This implies that selectorate members not included in the winning coalition require the challenger to cover their revolution costs and provide more public goods than the incumbent does.

\section{Revolution threshold}

$\bar{S}_{i}$ requires $e_{1}>k$ for a revolution while $\bar{W}_{i}$ requires $e_{1}>k+e_{0}(1-x)$. Since revolutions require participation from both groups, the opposition will revolt when $e_{1}>k+e_{0}(1-x)$.

Proposition 2 When the winning coalition proposes the incumbent, the opposition will revolt if $e_{1}>k+e_{0}(1-x)$ and accept the incumbent otherwise.

As $e_{1}$ follows a uniform distribution between 0 and 1, this requirement is fulfilled with probability $\rho=1-k-(1-x) e_{0}$. Furthermore, using backward induction, we know that the expected economic competence of the challenger conditional on having a revolution is $E\left(e_{1} \mid R\right)=\frac{1}{2}\left(1+k+e_{0}(1-x)\right)$.

\subsubsection{Winning coalition's expected utility}

In this subsection, we discuss the expected utility of winning coalition members.

The expected utility of proposing the challenger $\left(E U^{w_{i}}\left(C_{1}\right)\right)$ depends on the expected economic competence of the challenger, $E\left(e_{1}\right)$, and the probability of remaining in the coalition, $\frac{w}{s}$. In other words, if the challenger comes into power, then the sitting winning coalition will receive public goods for sure but private rents with probability $\frac{w}{s}$.

At the beginning of the period, the winning coalition does not know anything about the challenger, who is drawn randomly from the candidate pool. Since $e_{1} \sim U[0,1]$, the expected economic competence of the challenger, $E\left(e_{1}\right)$, equals $\frac{1}{2}$. The expected utility of proposing a challenger for the sitting winning coalition has two components: public goods and private rents. The public goods component amounts to $\mathrm{E}\left(\mathrm{e}_{1}\right)(1-\mathrm{x})$, while the private rents are $\mathrm{E}\left(\mathrm{e}_{1}\right) \frac{\mathrm{x}}{\mathrm{W}}$. Since the probability for members of the sitting winning coalition to stay in the winning coalition equals $\frac{\mathrm{W}}{\mathrm{S}}$, we get that expected private rents equal $\mathrm{E}\left(\mathrm{e}_{1}\right) \frac{\mathrm{X}}{\mathrm{S}}$. Therefore, the expected utility of $W_{i}$ when proposing the challenger is:

$$
E U^{w_{i}}\left(C_{1}\right)=\mathrm{E}\left(e_{1}\right) \frac{x}{w} \frac{w}{s}+\mathrm{E}\left(e_{1}\right)(1-x)=\frac{1}{2}\left(\frac{x}{s}+1-\mathrm{x}\right)
$$

Furthermore, the expected utility of $\mathrm{W}_{\mathrm{i}}$ when proposing the incumbent is:

$$
\begin{aligned}
E U^{w_{i}}\left(C_{0}\right)= & \rho\left(1-E\left(m_{0}\right)\right)\left(E\left(e_{1} \mid R\right)-k\right) \\
& +\left(1-\rho\left(1-E\left(m_{0}\right)\right)\right) e_{0}\left(\frac{x}{w}+1-x\right) \\
= & \alpha e_{0} \frac{1}{2}\left(1-k+e_{0}(1-x)\right)\left(1-k-(1-x) e_{0}\right) \\
& +\left(1-\alpha e_{0}\left(1-k-(1-x) e_{0}\right)\right) e_{0}\left(\frac{x}{w}+1-x\right)
\end{aligned}
$$

This equation has two components: (1) the expected utility after a successful revolution, which happens with probability $\rho\left(1-E\left(m_{0}\right)\right)$, where $\rho$ is the probability of a revolution attempt, and $\left.E\left(m_{0}\right)\right)$, which is the expected level of military competence of the incumbent, and (2) the expected utility without a revolution, which happens with probability $1-\rho\left(1-E\left(m_{0}\right)\right)$. The probability of having a successful revolution, $\left(1-E\left(m_{0}\right)\right) \rho$, can be expressed further as a U-shaped quadratic function of $e_{0}$. It implies that after $e_{0}$ reaches a 
certain level, greater economic competence induces a higher revolutionary threat. The reason is that, although the opposition is less likely to revolt when the incumbent is economically more competent, the incumbent cannot dismantle it when the opposition revolts.

\subsection{Leader survival}

The next step in our analysis goes from the expected utilities under the incumbent and the challenger to the expressions for leader survival.

The winning coalition will be more likely to stick with the incumbent if the incumbent provides larger payoffs than the challenger does. We assume that the incumbent's survival ratio $p^{s}, p^{s} \in[0,1]$, is a strictly increasing function of $\mathrm{d}$, which equals the difference between the expected utility of choosing the incumbent and that of choosing the challenger:

$$
d=E U^{w_{i}}\left(C_{0}\right)-E U^{w_{i}}\left(C_{1}\right)
$$

Inserting the expressions derived for expected utility under the incumbent and the challenger, respectively, we obtain:

$$
\begin{aligned}
d= & \alpha\left((1-x)\left(1+\frac{x}{w}\right)-\frac{1}{2}\left(1-x^{2}\right)\right) e_{0}^{3} \\
& -\alpha(1-k)\left(1-x+\frac{x}{w}\right) e_{0}^{2} \\
& +\left(1-x+\frac{x}{w}+\frac{\alpha}{2}(1-k)^{2}\right) e_{0} \\
& -\frac{1}{2}\left(\frac{x}{s}+1-x\right)
\end{aligned}
$$

Since the incumbent's survival ratio, $p^{s}$, is a function strictly increasing in $d$, the incumbent is more likely to survive as $d$ gets larger. We are interested in how the incumbent's economic competence affects his survival. To that end, we take the first derivative of $p^{s}$ with respect to $e_{0}$. As $\frac{\partial p^{s}}{\partial e_{0}}$ has the same sign as $\frac{\partial d}{\partial e_{0}}$, we calculate:

$$
\frac{\partial d}{\partial e_{0}}=3 \alpha(1-x)\left(\frac{1}{2}+\frac{x}{w}-\frac{x}{2}\right) e_{0}^{2}-2(1-k)\left(1-x+\frac{x}{w}\right) \alpha e_{0}+1-x+\frac{x}{w}+\frac{1}{2} \alpha(1-k)^{2}
$$

It can be observed immediately that the impact of competence on survival depends on the size of the winning coalition. Therefore, we focus on the more interesting case $\frac{\partial^{2} p^{s}}{\partial e_{0} \partial w}$ and explore further how the impact of $e_{0}$ on $p^{s}$ evolves with the size of the winning coalition, $w$, by calculating the second derivative $\frac{\partial^{2} d}{\partial e_{0} \partial w}$.

$$
\frac{\partial^{2} d}{\partial e_{0} \partial w}=-\frac{x}{w^{2}}\left(1-2(1-\mathrm{k}) \alpha e_{0}+3(1-x) \alpha e_{0}^{2}\right)
$$

On the basis of this equation, we consider how the incumbent's economic competence affects his survival rate and how this effect is moderated by the size of the winning coalition. 
As the model is based on the assumption of a revolutionary threat, we here consider only values of the exogenous parameters that are likely for such countries. That is, countries facing revolutionary threats mostly have low income levels (revolution cost, $k$, small) and high income inequality ( $x$ goes to 1 ). For these parameter values, we derive our main proposition. ${ }^{18}$

Hypothesis 1 In the presence of a revolutionary threat, an increase in economic competence reduces the probability of political survival (increases the hazard rate), but the magnitude of the effect depends on the size of the winning coalition. As the winning coalition grows larger, the probability of survival increases (the hazard rate declines). The opposite holds for the effect of military competence.

The reason for the moderating effect of the winning coalition's size is as follows. Members of the winning coalition obtain more public goods and private rents from an economically more competent incumbent as long as their access to private rents is secured. Under this circumstance, for a given level of military competence, they would always favor an economically more competent incumbent. However, economic competence comes at the cost of less military competence. Hence, for every unit of additional welfare (due to increased economic competence), they face a greater risk of losing private rents received under the incumbent (owing to less military competence). As long as the winning coalition is small, only a few members share the private rents. In such a case, winning coalition members have a strong preference for a military competent leader and therefore the hazard rate of economically competent leaders is high. However, when the winning coalition is larger, less private rents per head relative to public goods accrue to winning coalition members and an economically competent leader becomes more attractive.

As an extreme case, one could consider the situation when $w$ approaches 0 . In that case, winning coalition members have a strong preference for militarily competent incumbents. Despite the limited amount of output that is produced in such a case, the amount of private rents per winning coalition member grows so large that a militarily competent incumbent is always to be preferred. Even though, in practice, winning coalitions are never nil, empirically it would correspond to a regression model in which there is no interaction effect between the competence levels of the incumbent and the size of the winning coalition. In a model for which we estimate the unconditional effect of economic (military) competence on political survival we expect therefore a negative (positive) coefficient for the respective competence variable(s). ${ }^{19}$

\section{Model and data}

In the remainder of the paper, we test hypothesis 1 . Here, we describe our empirical model and data. As we test our hypothesis within the framework of Bueno de Mesquita and Smith (2010), our empirical strategy closely follows theirs. The emphasis of our data discussion below will be, therefore, on how we proxy for the competence levels of political leaders.

As to the empirical model, the selectorate theory predicts a decline over time in the hazard rate of political leaders and this decline is greater for leaders in small-coalition systems (Bueno de Mesquita and Smith 2010). The endogenous hazard rate makes the Cox

\footnotetext{
18 A proof with a numerical example and simulation can be found in the Appendix.

19 In fact, this is supported by the data. Results are available upon request.
} 
proportional hazard model inappropriate. Like Bueno de Mesquita and Smith (2010), we, therefore, estimate a parametric Weibull model where the hazard rate at year $t$ is

$$
h(t)=p \lambda t^{p-1}, \quad \text { where } p=f(w) \text { and } \lambda=\exp \left(\mathrm{X}_{i t}^{\prime} \boldsymbol{\beta}\right) .
$$

As suggested by Bueno de Mesquita and Smith (2010), the hazard rate declines faster over time for smaller coalitions (regardless of the competence levels of the political leader, that is). ${ }^{20}$ Thus, $p$ (the ancillary shape parameter) is modeled as a function of winning coalition size, $w$, to capture this feature of the hazard rate. In addition, $\lambda$ is equal to $\exp \left(\mathrm{X}_{i t}^{\prime} \boldsymbol{\beta}\right)$ ), where $\mathrm{X}_{i t}$ is a vector of independent variables measured for country $\mathrm{i}$ in year $\mathrm{t}$; $\boldsymbol{\beta}$ is a vector of coefficients corresponding to $\mathrm{X}_{i t}$. Throughout all model specifications, we follow Bueno de Mesquita and Smith (2010) and include the size of the winning coalition (w), the size of the selectorate(s), age of the incumbent (Age) and the interaction between age and the size of the winning coalition ( $\mathrm{w}^{*} \mathrm{Age}$ ) as control variables in the regressions. ${ }^{21}$ The observations on age are taken from the Archigos dataset. Additionally we control for GDP per capita (in natural logs) level and GDP's annual growth rate. These variables are taken from the World Bank Development Indicators 2013. ${ }^{22}$

The dependent variable of our study is the hazard rate of political leaders. To measure leader changes, we use the Archigos dataset of Goemans et al. (2009). This dataset contains information on the dates of entry and exit from office for the effective leader of every independent country. The effective leader is that individual who exercised de facto political power in the country, which can be a president, a king, a prime minister, and so forth. The dataset contains information on 2098 leaders in 188 countries for the period from 1875 to 2004 . However, as our model applies only to countries facing a revolutionary threat, we only use sub-samples of political leaders. In particular, we focus on nondemocratic leaders and leaders who were in power in times of (greater) political unrest. We propose to distinguish between democracies and autocracies, as revolutionary threats may be less likely in democracies than in autocracies. To distinguish between political systems, we rely on the classification of Cheibub et al. (2010). As to distinguishing between political leaders that face political turmoil and other leaders, we take the measure proposed by Bueno de Mesquita and Smith (2010), which is based on the change in the level of mass demonstrations, riots, strikes and revolutions over a three-year period (labeled as Mass3). In turn, we focus on countries that faced sharp increases or reductions in mass civil protests and revolutions. ${ }^{23}$

\footnotetext{
${ }^{20}$ To test for robustness, we also estimated our model using other distributional assumptions for the shape of the hazard rate, such as Gompertz, Log-Logistic, Log-normal, exponential and the gamma distribution. We find the lowest AIC and BIC statistics for our proposed Weibull model. Furthermore, our results are not sensitive to any of the assumptions made. Results are available upon request.

21 We also follow the approach of Bueno de Mesquita and Smith (2010) by using time-varying covariates. We have estimated our model also using alternative treatments of the covariates, such as including lagged values, initial values, or duration-specific averages, but this did not alter our findings. The results are available upon request.

22 Bueno de Mesquita and Smith (2010) included other controls, such as the non-tax revenue, official development assistance and net oil exports, all as percentages of GDP. However, including these controls significantly shrinks our dataset. Thus, we follow them by including only the current GDP per capita level and annual growth rate. Additionally, we tested those controls' lagged values, tenure averages, and the values at the beginning of tenures. The main results remain the same.

23 Bueno de Mesquita and Smith (2010) construct an index measuring the level of mass political events. This index is based on antigovernment demonstrations, riots, general strikes and revolutions, which are taken from Banks and Wilson (2007). Their index is an equally weighted sum of the four measures of mass
} 
Our main explanatory variables are economic and military competence of the political leader. As a proxy for economic competence we follow Besley et al. (2011), who find that better educated leaders cause better economic outcomes and, therefore, we use data on the educational attainment of the political leader obtained before entering office. Likewise, we use data on military ranks (held before entering office) to proxy for military competence.

Our data on leader characteristics are taken mainly from Ludwig (2002), but supplemented with information from other sources. ${ }^{24}$ Following Ludwig (2002), the educational attainment of a leader is categorized as follows: (1) illiterate (no formal education); (2) literate (no formal education); (3) elementary/primary school education or tutors; (4) high/ finishing/secondary/trade school; (5) special training (beyond high school, such as mechanical, nursing, art, music, or military training ${ }^{25}$; (6) college educated; (7) qualifications from a graduate or professional school (e.g., master's degree); and (8) doctorates (e.g., Ph.D.). To maintain consistency with, e.g. Besley and Reynal-Querol (2011), we transform the eight-way classification into a four-way classification (labeled: Education4). Education 4 contains discrete numbers from 0 to 3 and has a value of zero if the educational attainment is below the college level, 1 if leaders have a college degree, 2 if leaders have a master's degree, and 3 if leaders have a Ph.D. degree. ${ }^{26}$ We have information on educational attainment for 1710 political leaders, but (in line with our theoretical model) will focus below only on political leaders of autocratic countries and leaders that have faced revolutionary threats.

Apart from absolute educational attainment, we also construct two relative measures because, for example, a college graduate in a country like Chad (where the literacy rate is only about $35 \%),{ }^{27}$ is considered to be highly educated whereas in a developed country like Canada $50 \%$ of the population has a bachelor's degree. Our relative measure is based on the political leader's educational attainment relative to years of education of the average citizen of the country. ${ }^{28}$ For country-level data on educational attainment, we use

Footnote 23 continued

political movements after standardization. Unfortunately, Banks's measures rely on media coverage, which may contain reporting biases and societal norms. To ameliorate these potential problems, Bueno de Mesquita and Smith (2010) suggest using the change in the level of mass political events over the previous 3 years (i.e., Mass3). For the same reason, we also use Mass3 as our preferred measure of mass movements. For more details, see Bueno de Mesquita and Smith (2010). Our empirical results do not change if the original measure (based on levels) is entered.

24 The priority order regarding the source of our data collection is: (1) Ludwig (2002); (2) Encyclopedia Britannica; (3) Keesing's World News Archive, (4) Series of Who's Who and LexContent5 (provided by LexisNexis Academic search); (5) Biographies on government websites; (6) www.rulers.org; and (7) Wikipedia. We compared the information collected from the first six sources with Besley and Reynal-Querol (2011) and conclude that the datasets correlate highly ( $\mathrm{r}=0.93)$. We used Besley and Reynal-Querol (2011) to fill in few gaps in our dataset.

25 Military training programs that do not confer a bachelor's degree fall into this category. These programs normally issue a certificate rather than a degree after completion. Military academy graduates are counted as college graduates.

${ }^{26}$ Using an eight-way classification instead of a four-way classification does not alter any of our findings. The results are available upon request.

27 https://www.cia.gov/library/publications/the-world-factbook/fields/2103.html.

${ }^{28}$ To construct this measure, we follow the mapping of Besley and Reynal-Querol (2011) of educational attainment into years: (1) illiterate (no formal education) $=0$ years; (2) literate (no formal education) $=2$ years; (3) grade/elementary/primary school or tutors $=6$ years; (4) high/finishing/secondary/trade school $=12$ years $(+6) ;(5)$ special training (beyond high school, such as mechanical, nursing, art, music or military training $)=16(+4)$ years; $(6)$ college $=16(+4)$ years; $(7)$ graduate or professional school (e.g., master's degree) $=18$ years $(+2)$; $(8)$ doctorate (e.g., Ph.D. $)=20$ years $(+2)$. 
Table 1 Ranks of NATO army officers

\begin{tabular}{llll}
\hline NATO code & UK & US & FR \\
\hline OF-10 & Field Marshal & General of the Army & Marechal de France \\
OF-9 & General & General & General d'Armree \\
OF-8 & Lieutenant-General & Lieutenant-General & General de Corps d'Armree \\
OF-7 & Major-General & Major-General & General de Division \\
OF-6 & Brigadier & Brigadier-General & General de Brigade \\
OF-5 & Colonel & Colonel & Colonel \\
OF-4 & Lieutenant-Colonel & Lieutenant-Colonel & Lieutenant-Colonel \\
OF-3 & Major & Major & Commandant \\
OF-2 & Captain & Captain & Capitaine \\
OF-1 & Lieutenant & First Lieutenant & Lieutenant \\
& Second Lieutenant & Second Lieutenant & Sous-Lieutenant \\
\hline
\end{tabular}

Source STANAG 2116 NATO chart (https://en.wikipedia.org/wiki/Ranks_and_insignia_of_NATO_armies_ officers)

information from Barro and Lee (2013) (this relative measure is labeled Education distance $(B L))$ and, to obtain a longer time series, from Morrisson and Murtin (2012) (this relative measure is labeled Education distance $(M M))$.

We construct measures of military competence on the basis of military rank. We categorize leaders according to the highest military rank they have reached before they assume power. We adopt the NATO coding with respect to the ranking of officers, which goes from OF-1 (e.g., Lieutenant in the United States) to OF-10 (e.g., five-star US General, a rank filled only in wartime) and construct a variable (labeled: NATO rank that goes from 0 (civilian or ranks below $\mathrm{OF}-1)$ to $10(\mathrm{OF}-10)){ }^{29}$

We consider the military rank of a political leader to be a good proxy for military competence as it can capture how well the incumbent is able to avoid the uprising of the opposition (or defeat the opposition). This can be either because high ranked leaders have superb military and tactical skills, but also because they have stronger ties to the military to protect their position and that of the political elite.

To maintain consistency between our competence variables, we also construct a measure based on four categories for military competence (Military4). This variable is categorized as follows. (1) Civilians (with no prior military experience); (2) low-ranked officers (from OF-1 to OF-4); (3) middle-ranked officers (from OF-5 to OF-8); and (4) high-ranked officers (OF-9 to OF-10). This variable, together with Education4, are the key explanatory variables in our empirical analysis.

As Education4 and Military4 are categorical variables, we present summary data in a two-way table in Table 2 and test the independence of the two competence dimensions using a $\chi 2$ test. We reject the null-hypothesis of independence at the $1 \%$ significance level. ${ }^{30}$

To examine the relation between educational and military attainment further, we show in Fig. 2 the conditional distribution of military attainment for different levels of educational attainment. As educational attainment increases from less than college to doctorate, the proportion of civilians rises from below $60 \%$ to around $95 \%$. In

\footnotetext{
29 An overview of the NATO coding is provided in Table 1.

30 Pearson Chi squared $(9)=161.1754, \operatorname{Pr}=0.000$.
} 
Table 2 Two-way table (education attainment and military attainment)

\begin{tabular}{|c|c|c|c|c|c|}
\hline $\begin{array}{l}\text { Education } \\
\text { attainment } \\
\text { Military } \\
\text { attainment }\end{array}$ & $\begin{array}{l}\text { Lower than } \\
\text { college } \\
(\text { Education } 4=0)\end{array}$ & $\begin{array}{l}\text { College } \\
(\text { Education } 4=1)\end{array}$ & $\begin{array}{l}\text { Master } \\
(\text { Education4= 2) }\end{array}$ & $\begin{array}{l}\text { Doctorate } \\
(\text { Education4= 3) }\end{array}$ & Total \\
\hline $\begin{array}{l}\text { Civilian } \\
\quad(\text { Military4 }=0)\end{array}$ & $258(312.7)$ & $467(515.7)$ & $292(237.2)$ & $301(152.4)$ & $1218(1218.0)$ \\
\hline $\begin{array}{l}\text { Low-rank officer } \\
\quad(\text { Military4 = 1) }\end{array}$ & $70(40.6)$ & $65(66.9)$ & $19(30.8)$ & $4(19.8)$ & $158(158.0)$ \\
\hline $\begin{array}{l}\text { Middle-rank } \\
\text { officer } \\
\quad(\text { Military4 = 2) }\end{array}$ & $36(28.5)$ & $62(47.0)$ & 8 (21.6) & $5(13.9)$ & $111(111.0)$ \\
\hline $\begin{array}{l}\text { High-rank officer } \\
\text { (Military } \\
\quad 4=3 \text { ) }\end{array}$ & $75(57.2)$ & $130(94.4)$ & $14(43.4)$ & $4(27.9)$ & $223(223.0)$ \\
\hline Total & 439 & 724 & 333 & 314 & 1710 \\
\hline
\end{tabular}

Pearson $\operatorname{chi} 2(9)=161.1754, \operatorname{Pr}=0.000$

Expected counts are reported in parentheses

addition, the proportion of high-rank officers is greater in categories of lesser educational attainment. For leaders with college/less than a college education, around $20 \%$ have a high-rank military background, while for leaders with a master's or Ph.D. degree, fewer than $5 \%$ attain a high military rank. From this, we cannot merely conclude that the two competence dimensions are correlated. We can also conclude that they are substitutes.

To test proposition 1, we also require data on winning coalition size and selectorate size. To that end, we follow Bueno de Mesquita and Smith (2010), who have extended the work of Bueno de Mesquita et al. (2003), and construct $w$ (the size of the winning coalition) on the basis of Polity IV data and Banks and Wilson (2007). It is constructed as follows: 0.25 points are added to $w$ for each of the following conditions that is fulfilled within a country: (1) if the regime type is defined as nonmilitary according to Banks and Wilson (2007); (2) if the chief executive is not chosen by heredity or in rigged, unopposed elections (i.e., the variable $X R C O M P \geq 2$, according to Polity IV); (3) if the executive is recruited openly (i.e., the variable $X R O P E N>2$ according to Polity IV); and (4) if a competitive party system is in place (i.e., the variable, PARCOMP $=5$, according to Polity IV). As a result, $w$ ranges from 0 to $1 .^{31}$ The selectorate size, $s$, is constructed using Banks and Wilson's (2007) legislative selection variable, which is coded zero if there is no legislature, one if the selection is non-elective (as is the case in heredity or ascription), and 2 if the legislature is elected. Dividing the legislative selection variable by 2 yields a measure for $\mathrm{s}$ that also lies between 0 and 1 . The availability of $s$ and $w$ reduces our sample to 166 countries. $^{32}$

\footnotetext{
31 It should be noted that a one-to-one mapping between the selectorate theory and the proxy at hand does not exist (Clarke and Stone 2008). Yet, Bueno de Mesquita et al. (2008) argue that, despite this obvious limitation, the proxies reflect the winning coalition and the selectorate, respectively, in the theoretically predicted direction.
}

32 A summary of all descriptive statistics related to our data is reported in Table 9. 


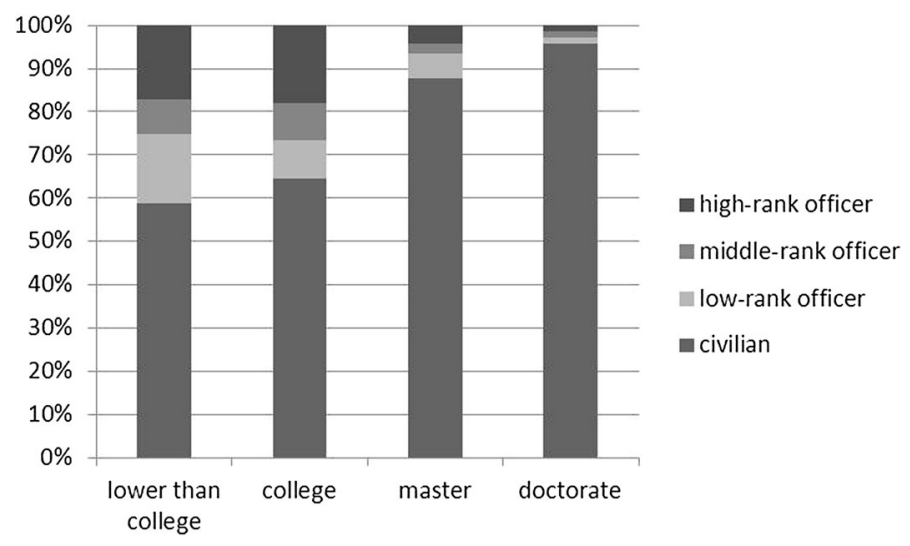

Fig. 2 The distribution of military ranks for different education attainments

\section{Empirical results}

We estimate in Tables 3 and 4 models similar to Bueno de Mesquita and Smith (2010). Whereas Table 4 focuses on the subsample containing autocratic political leaders, Table 3 focuses on political leaders that have been in power during times of political uprising (in both democracies and autocracies).

In column 1 of Tables 3 and 4, we test the impact of economic competence (and its interaction with the size of the winning coalition) on political survival. In column 2 of the respective tables, we replace economic competence by military competence. In column 3 , we enter both competence variables and their interaction with the size of the winning coalition simultaneously and, lastly, in column 4 we add additional control variables that are also used by Bueno de Mesquita and Smith (2010). ${ }^{33}$

We observe that the variables of interest in our model are estimated with the expected sign and are significant at (at least) the $5 \%$ significance level. To interpret our results regarding proposition 1 , we calculate the marginal effect of educational attainment and military attainment on the leader's hazard rate for different sizes of the winning coalition (based on the estimates in columns (3) of Tables 3 and 4). The results are plotted in Figs. 3 and 4. It can be seen in the left panel that the marginal effect of educational attainment is significant for small winning coalitions as both lines of the $95 \%$ confidence interval are above zero. This implies that highly educated leaders have the highest hazard rates when the winning coalition is small. This effect, however, disappears when $\mathrm{w}$ goes to 1 . The reverse holds for military attainment (right panel), i.e., leaders with higher military ranks are more likely to survive in small-coalition regimes, while this is not necessarily true in large-coalition regimes.

In addition, most of the control variables in Tables 3 and 4 are significant. We find that small winning coalitions and big selectorates reduce the hazard rate. Bueno de Mesquita and Smith (2010) explain that a larger selectorate implies a smaller probability of being part of the winning coalition. Knowing this, members of the winning coalition

\footnotetext{
${ }^{33}$ Unfortunately, adding these additional control variables reduces our sample to about 1500 observations, which is approximately a reduction of $30 \%$. We, therefore, proceed with the larger sample and for the most part base our conclusions on the results obtained from it.
} 

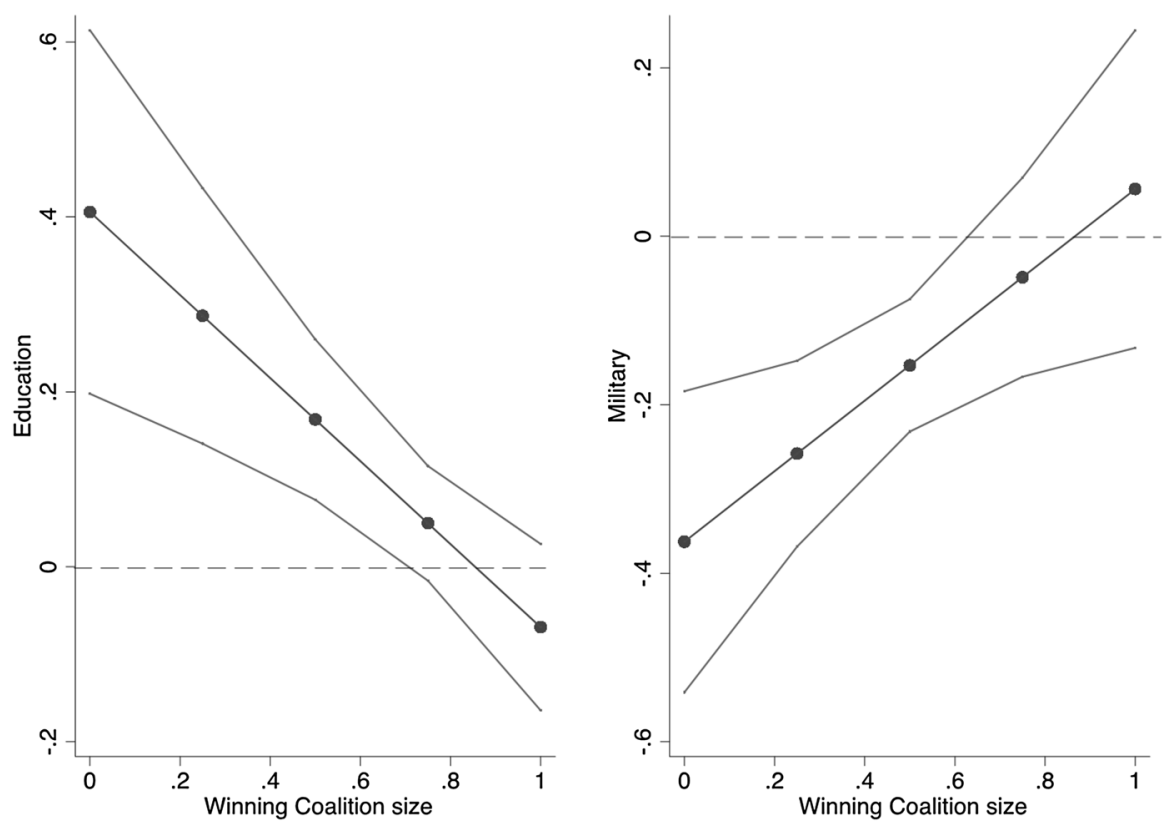

Fig. 3 The ME of Education4/Military4 on leader's hazard rate (when facing uprisings). The figure shows the marginal effect of the impact of leader's education attainment (left)/military attainment (right) on leader's hazard rate (vertical axis) for different values of w (horizontal axis). The estimates are taken from Table 3, column (3) where leaders are facing uprisings. Furthermore, the $95 \%$ confidence interval is plotted (solid lines). The dots refer to the observations indicate the value of $\mathrm{w}$ for all observations included the sample. The tight dots refer to when the marginal effect is zero

prefer to stick with the incumbent, which implies a lower hazard rate. Naturally, the opposite holds for the size of the winning coalition as, by definition, the probability of being part of the winning coalition is low when the size of the coalition is small. In all of our specifications, the age of the incumbent has a positive effect on the hazard rate. As the incumbent ages, the chances rise that he either will die a natural death, or that he will be replaced. Again, this effect is moderated by the size of the winning coalition. Not surprisingly, high-income levels and high economic growth rates are associated with low hazard rates.

As explained above, crucial to our model is the assumption that the winning coalition (and the political leader) is facing a threat of revolution. Therefore, we expect that our empirical results will not hold up if we select a sample in which leaders do not face such a threat. To that end, we show results in Table 5 for subsamples with (i.e., the odd columns) and without a revolutionary threat (i.e., the even columns). That is, we also run placebo regressions on a sample of countries that are stable with respect to mass political uprisings (columns 2 and 4) as well as a sample of democracies (columns 6 and 8). Our results confirm our hypothesis. That is, the estimated coefficients of the models reported in the even columns (i.e., countries without a revolutionary threat) are by and large all insignificant. 

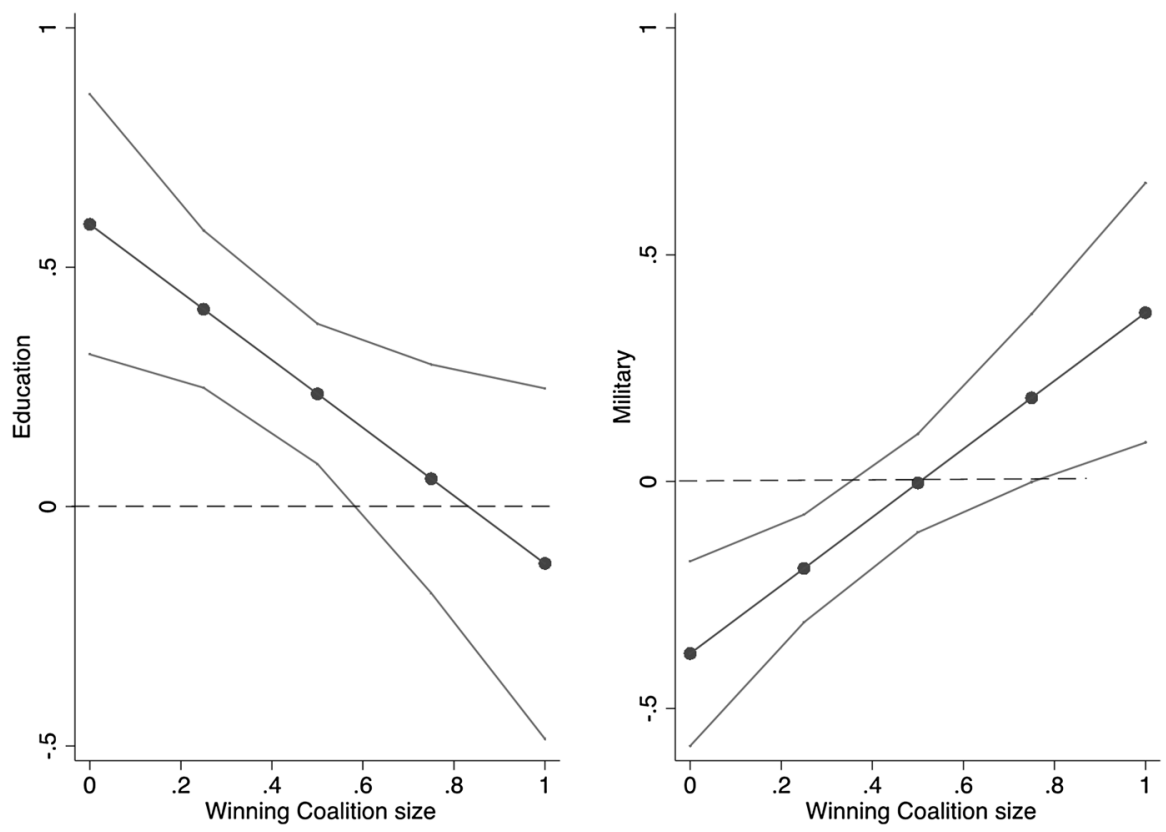

Fig. 4 The ME of Education4/Military4 on leader's hazard rate. (in autocracies). The figure shows the marginal effect of the impact of leader's education attainment (left)/military attainment (right) on leader's hazard rate (vertical axis) for different values of w (horizontal axis). The estimates are taken from Table 4, column (3) where leaders are from autocracies. Furthermore, the $95 \%$ confidence interval is plotted (solid lines). The dots refer to the observations indicate the value of $\mathrm{w}$ for all observations included the sample. The tight dots refer to when the marginal effect is zero

\section{Robustness analysis}

To probe the robustness of our results, we provide in Table 6 (for leaders facing political turmoil) and in Table 7 (for autocratic leaders) estimates using alternative measures of economic competency. We have reflected on these alternative measures in the data section. In column 1, we replace our economic competence measure by the measure proposed by Besley and Reynal-Querol (2011), which is the number of years of schooling that the leader obtained. In columns 2 and 3, we insert educational attainment of the leader relative to the average citizen of the country. In column 2 , the average educational attainment is proxied by the measure of Barro and Lee (2013), while in column 3 we use the measure of Morrisson and Murtin (2012). In column 4, we follow Besley et al. (2011) and insert two dummy variables for educational attainment. The first dummy is equal to one if the leader has at least a college degree, while the second dummy is equal to one if the leader has at least a master's degree. In all cases we find that the coefficient of educational attainment is positive while the interaction term is negative, which lends support for our hypothesis. However, in the case of educational distance (columns 2 and 3 of Table 6), the estimate is not significant.

As to military attainment, we check for robustness in two ways. First, we treat the NATO classification as a numeric variable. Second, we insert dummy variables capturing low-rank officers, middle rank officers and high-rank officers. In both cases we find that the estimated coefficients are of the expected sign and all significant at the $1 \%$ significance 
Table 3 Leader survival facing political uprising

\begin{tabular}{|c|c|c|c|c|c|}
\hline & & (1) & (2) & (3) & (4) \\
\hline \multirow[t]{26}{*}{$-\mathrm{t}$} & \multirow[t]{2}{*}{ Education4 } & $0.554 * * *$ & & $0.406^{* * * *}$ & $0.309 * *$ \\
\hline & & $(0.103)$ & & $(0.106)$ & $(0.130)$ \\
\hline & \multirow[t]{2}{*}{$\mathrm{w} *$ Education 4} & $-0.650 * * *$ & & $-0.475 * * *$ & $-0.374 * *$ \\
\hline & & $(0.135)$ & & $(0.136)$ & $(0.170)$ \\
\hline & \multirow[t]{2}{*}{ Military4 } & & $-0.436 * * *$ & $-0.363 * * *$ & $-0.418 * * *$ \\
\hline & & & $(0.087)$ & $(0.091)$ & $(0.108)$ \\
\hline & \multirow[t]{2}{*}{ w*Military4 } & & $0.506^{* * * *}$ & $0.419 * *$ & $0.544 * * *$ \\
\hline & & & $(0.166)$ & $(0.169)$ & $(0.172)$ \\
\hline & \multirow[t]{2}{*}{$\operatorname{Ln}(\mathrm{GDPpc})$} & & & & -0.078 \\
\hline & & & & & $(0.107)$ \\
\hline & \multirow[t]{2}{*}{$\mathrm{w} * \operatorname{Ln}(\mathrm{GDPpc})$} & & & & 0.134 \\
\hline & & & & & $(0.129)$ \\
\hline & \multirow[t]{2}{*}{ Growth } & & & & $-0.025 * * *$ \\
\hline & & & & & $(0.007)$ \\
\hline & \multirow[t]{2}{*}{$\mathrm{w} *$ Growth } & & & & 0.026 \\
\hline & & & & & $(0.020)$ \\
\hline & \multirow[t]{2}{*}{$\mathrm{W}$} & $3.776 * * *$ & $1.733 * *$ & $2.932 * * *$ & 1.952 \\
\hline & & $(0.732)$ & $(0.744)$ & $(0.770)$ & (1.214) \\
\hline & \multirow[t]{2}{*}{$\mathrm{s}$} & $-0.802 * * *$ & $-0.679 * * *$ & $-0.866 * * *$ & $-1.136^{* * *}$ \\
\hline & & $(0.137)$ & $(0.144)$ & $(0.137)$ & $(0.167)$ \\
\hline & \multirow[t]{2}{*}{ Age } & $0.039 * * *$ & $0.034 * * *$ & $0.037 * * *$ & $0.042 * * *$ \\
\hline & & $(0.008)$ & $(0.007)$ & $(0.008)$ & $(0.010)$ \\
\hline & \multirow[t]{2}{*}{ w*Age } & $-0.048 * * *$ & $-0.041 * * *$ & $-0.045^{* * *}$ & $-0.050 * * *$ \\
\hline & & $(0.012)$ & $(0.011)$ & $(0.012)$ & $(0.016)$ \\
\hline & \multirow[t]{2}{*}{ Constant } & $-3.382 * * *$ & $-1.665 * * *$ & $-2.603 * * *$ & $-2.078 * * *$ \\
\hline & & $(0.430)$ & $(0.412)$ & $(0.462)$ & $(0.751)$ \\
\hline \multirow[t]{9}{*}{$\operatorname{Ln}(p)$} & \multirow[t]{2}{*}{ w } & 0.275 & $0.422 * *$ & 0.286 & $0.270^{*}$ \\
\hline & & $(0.173)$ & $(0.167)$ & $(0.185)$ & $(0.151)$ \\
\hline & \multirow[t]{2}{*}{ Constant } & $-0.363 * * *$ & $-0.551 * * *$ & $-0.375 * * *$ & $-0.262 * * *$ \\
\hline & & $(0.095)$ & $(0.083)$ & $(0.100)$ & $(0.096)$ \\
\hline & Observations & 4658 & 4810 & 4658 & 2985 \\
\hline & Log Lik & -1614 & -1877 & -1597 & -892.4 \\
\hline & Ncountry & 160 & 160 & 160 & 144 \\
\hline & Nsubject & 1382 & 1501 & 1382 & 859 \\
\hline & Nfailure & 936 & 1042 & 936 & 590 \\
\hline
\end{tabular}

Here a parametric Weibull model is estimated with the hazard rate at year t being the dependent variable. The ancillary shape parameter, $\mathrm{p}$, is a function of $\mathrm{w}$. The sample is restricted to leaders that have been in power during times of political uprising. Political uprising is defined as changes in the level of mass demonstrations, riots, strikes and revolutions over a three-year period (Mass $3>0$ ). Robust standard errors in parentheses, *** $\mathrm{p}<0.01, * * \mathrm{p}<0.05, * \mathrm{p}<0.1$

level. One notable result is that the coefficients on high-rank officers are larger than the coefficients on middle/low-rank officers, which suggests that especially high-rank officers are able to secure their position in office. 
Table 4 Leader survival in autocracies

\begin{tabular}{|c|c|c|c|c|c|}
\hline & & (1) & (2) & (3) & (4) \\
\hline \multirow[t]{26}{*}{$-\mathrm{t}$} & \multirow[t]{2}{*}{ Education4 } & $0.739 * * *$ & & $0.590 * * *$ & $0.414 * * *$ \\
\hline & & $(0.115)$ & & $(0.139)$ & $(0.149)$ \\
\hline & \multirow[t]{2}{*}{$\mathrm{w}^{*}$ Education 4} & $-1.039 * * *$ & & $-0.709 * *$ & -0.513 \\
\hline & & $(0.247)$ & & $(0.293)$ & $(0.316)$ \\
\hline & \multirow[t]{2}{*}{ Military4 } & & $-0.471 * * *$ & $-0.379 * * *$ & $-0.405^{* * *}$ \\
\hline & & & $(0.097)$ & $(0.104)$ & $(0.120)$ \\
\hline & \multirow[t]{2}{*}{$\mathrm{w} *$ Military4 } & & $0.904 * * *$ & $0.752^{* * * *}$ & $0.738 * * *$ \\
\hline & & & $(0.220)$ & $(0.228)$ & $(0.276)$ \\
\hline & \multirow[t]{2}{*}{$\operatorname{Ln}(\mathrm{GDPpc})$} & & & & $-0.410 * * *$ \\
\hline & & & & & $(0.122)$ \\
\hline & \multirow[t]{2}{*}{$\mathrm{w}^{*} \operatorname{Ln}(\mathrm{GDPpc})$} & & & & $1.009 * * *$ \\
\hline & & & & & $(0.252)$ \\
\hline & \multirow[t]{2}{*}{ Growth } & & & & $-0.017 * *$ \\
\hline & & & & & $(0.009)$ \\
\hline & \multirow[t]{2}{*}{$\mathrm{w}^{*}$ Growth } & & & & -0.020 \\
\hline & & & & & $(0.042)$ \\
\hline & \multirow[t]{2}{*}{ w } & $4.282 * * *$ & 1.123 & 2.490 & -1.907 \\
\hline & & $(1.589)$ & $(1.432)$ & (1.692) & $(2.527)$ \\
\hline & \multirow[t]{2}{*}{$\mathrm{s}$} & $-1.044 * * *$ & $-0.748 * * *$ & $-1.011 * * *$ & $-1.224 * * *$ \\
\hline & & $(0.177)$ & $(0.193)$ & $(0.182)$ & $(0.208)$ \\
\hline & \multirow[t]{2}{*}{ Age } & $0.043 * * *$ & $0.036^{* * *} *$ & $0.039 * * *$ & $0.065^{* * *}$ \\
\hline & & $(0.011)$ & $(0.010)$ & $(0.011)$ & $(0.012)$ \\
\hline & \multirow[t]{2}{*}{ w*Age } & $-0.048^{*}$ & -0.039 & -0.039 & $-0.085^{* * *}$ \\
\hline & & $(0.029)$ & $(0.026)$ & $(0.030)$ & $(0.032)$ \\
\hline & \multirow[t]{2}{*}{ Constant } & $-4.144 * * *$ & $-2.038 * * *$ & $-3.236 * * *$ & $-1.588^{*}$ \\
\hline & & $(0.615)$ & $(0.491)$ & $(0.649)$ & $(0.885)$ \\
\hline \multirow[t]{9}{*}{$\operatorname{Ln}(p)$} & \multirow[t]{2}{*}{ w } & $-0.458^{*}$ & $-0.414^{*}$ & $-0.531 * *$ & -0.394 \\
\hline & & $(0.236)$ & $(0.249)$ & $(0.268)$ & $(0.294)$ \\
\hline & \multirow[t]{2}{*}{ Constant } & -0.141 & $-0.355^{* * *}$ & -0.134 & -0.135 \\
\hline & & $(0.094)$ & $(0.093)$ & $(0.101)$ & $(0.111)$ \\
\hline & Observations & 4517 & 4623 & 4517 & 3006 \\
\hline & Log Lik & -804.6 & -1013 & -790.9 & -501.3 \\
\hline & Ncountry & 124 & 124 & 124 & 109 \\
\hline & Nsubject & 591 & 665 & 591 & 415 \\
\hline & Nfailure & 407 & 474 & 407 & 291 \\
\hline
\end{tabular}

Here a parametric Weibull model is estimated with the hazard rate at year t being the dependent variable. The ancillary shape parameter, $\mathrm{p}$, is a function of $\mathrm{w}$. The sample is restricted to leaders in autocratic regimes. Robust standard errors in parentheses, $* * * \mathrm{p}<0.01$, ** $\mathrm{p}<0.05, * \mathrm{p}<0.1$

To further examine the robustness of our results, we analyze different subsamples of our data set. These results are reported in Table 8 .

In column 1 and 2 of Table 8, observations from sub-Saharan Africa are removed from the sample. Leaders who reached power by irregular means are dropped in columns 3 and 4 and, furthermore, columns 5 and 6 include observations only on leaders who reached 


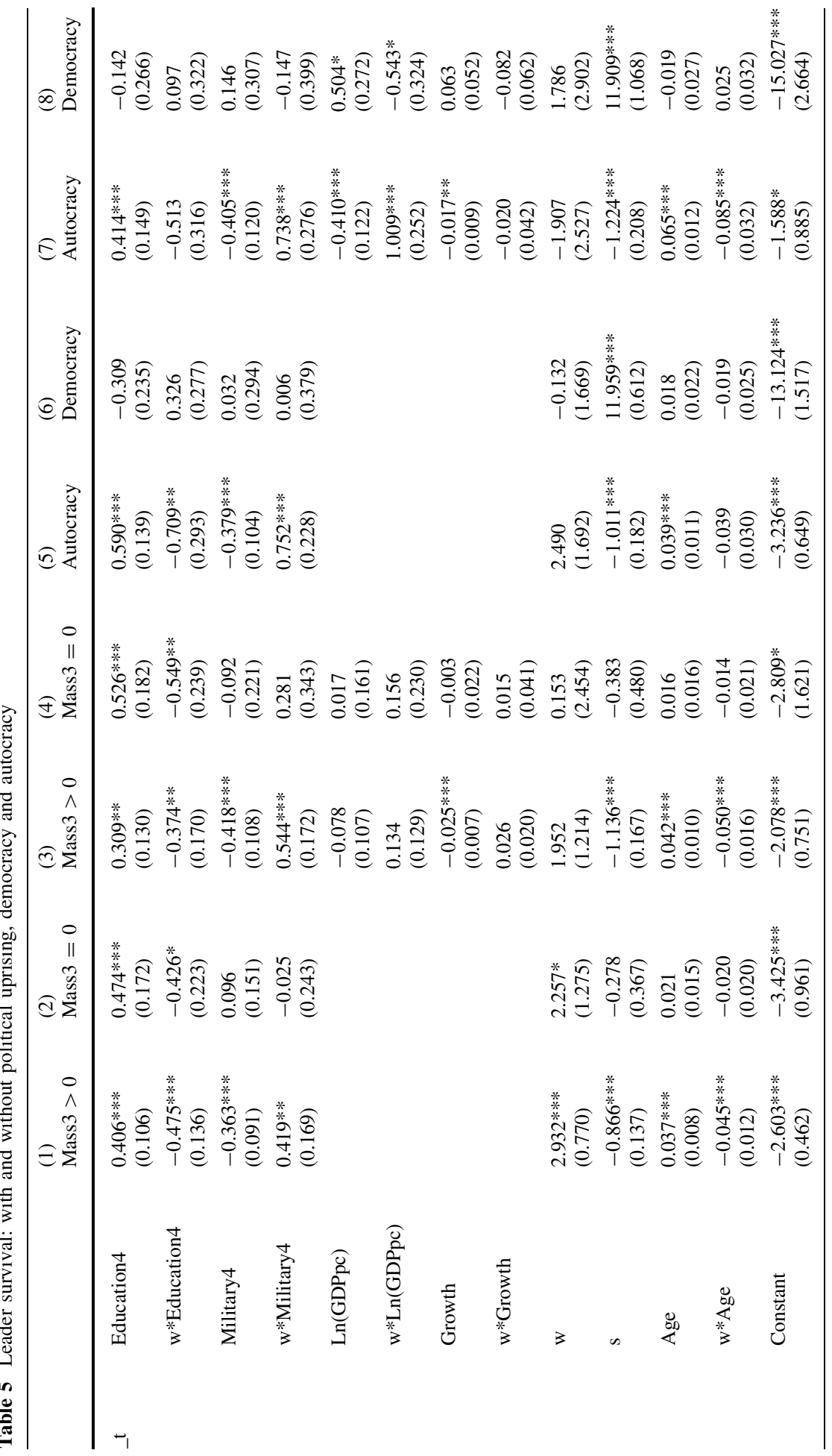




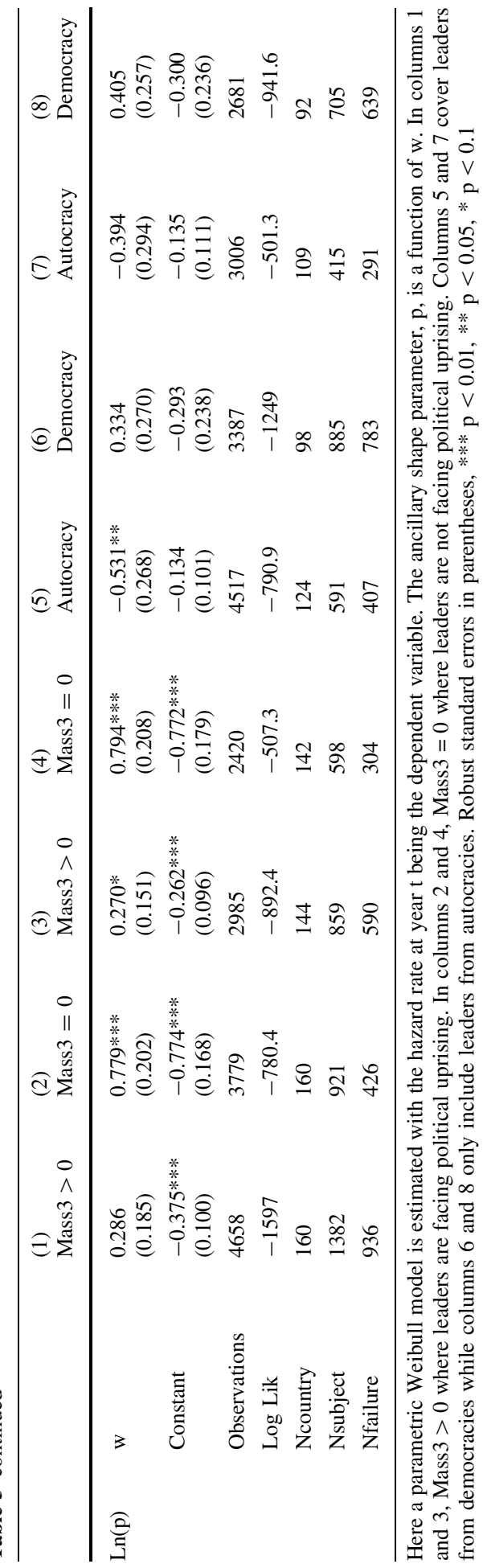




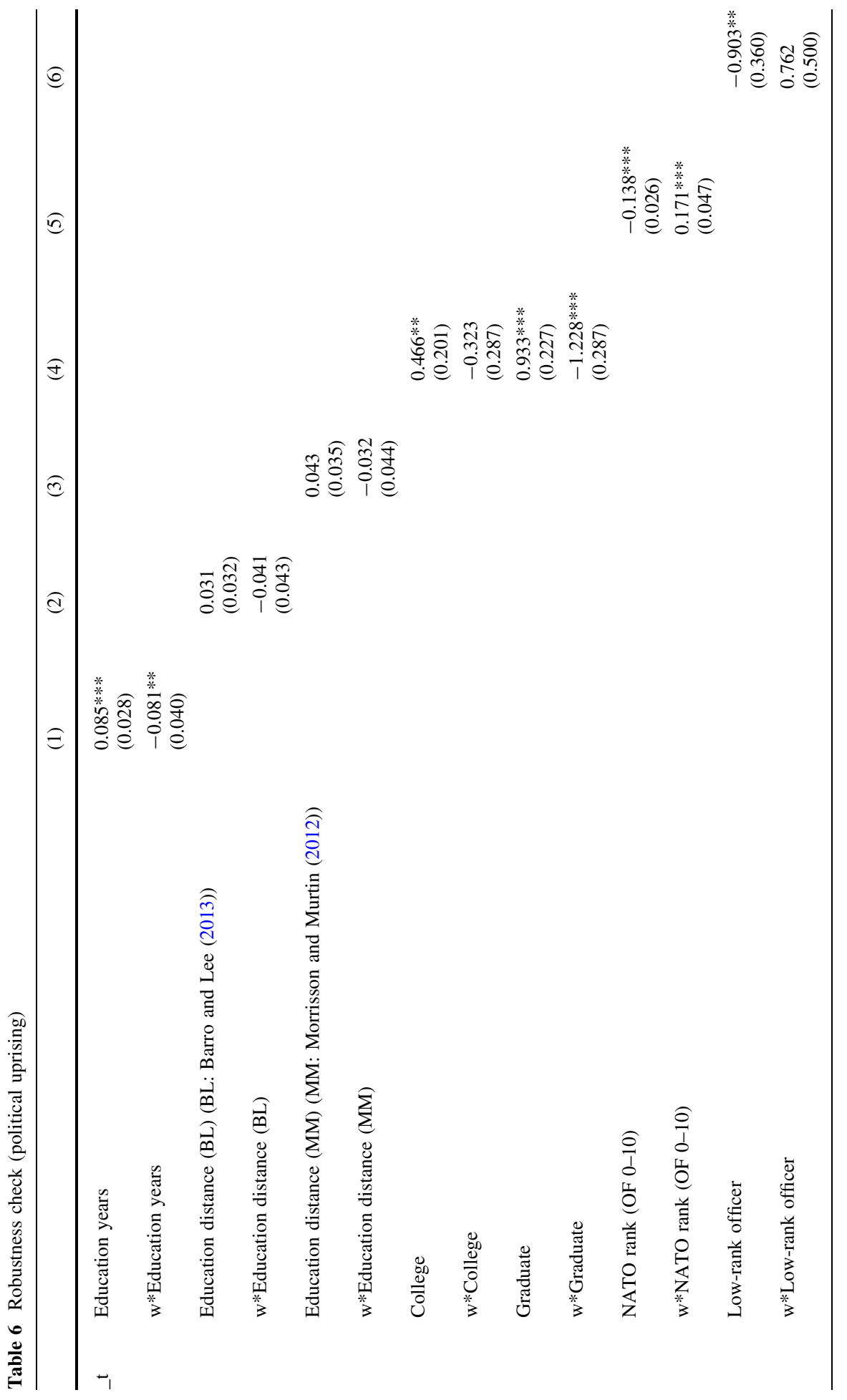




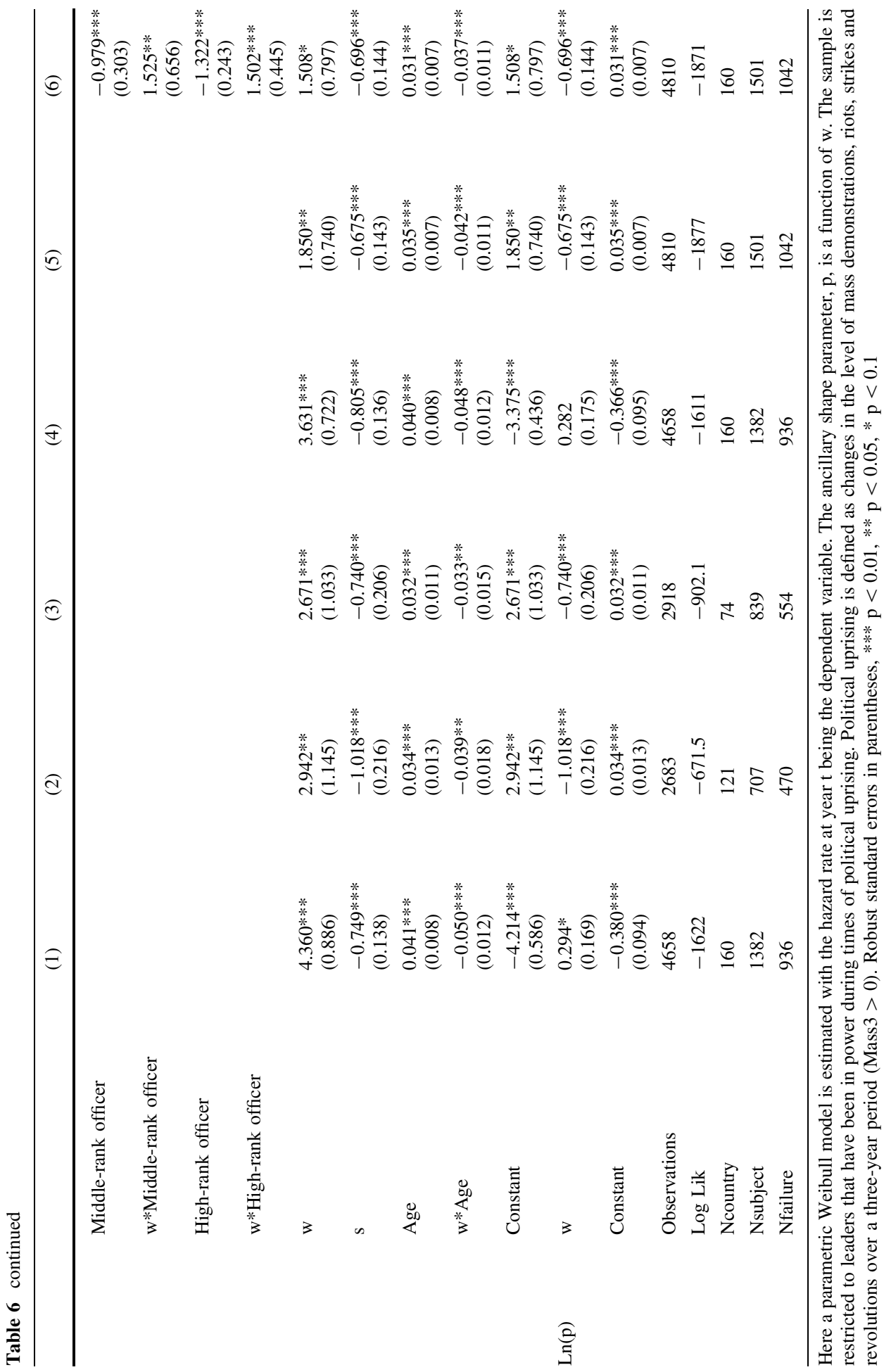




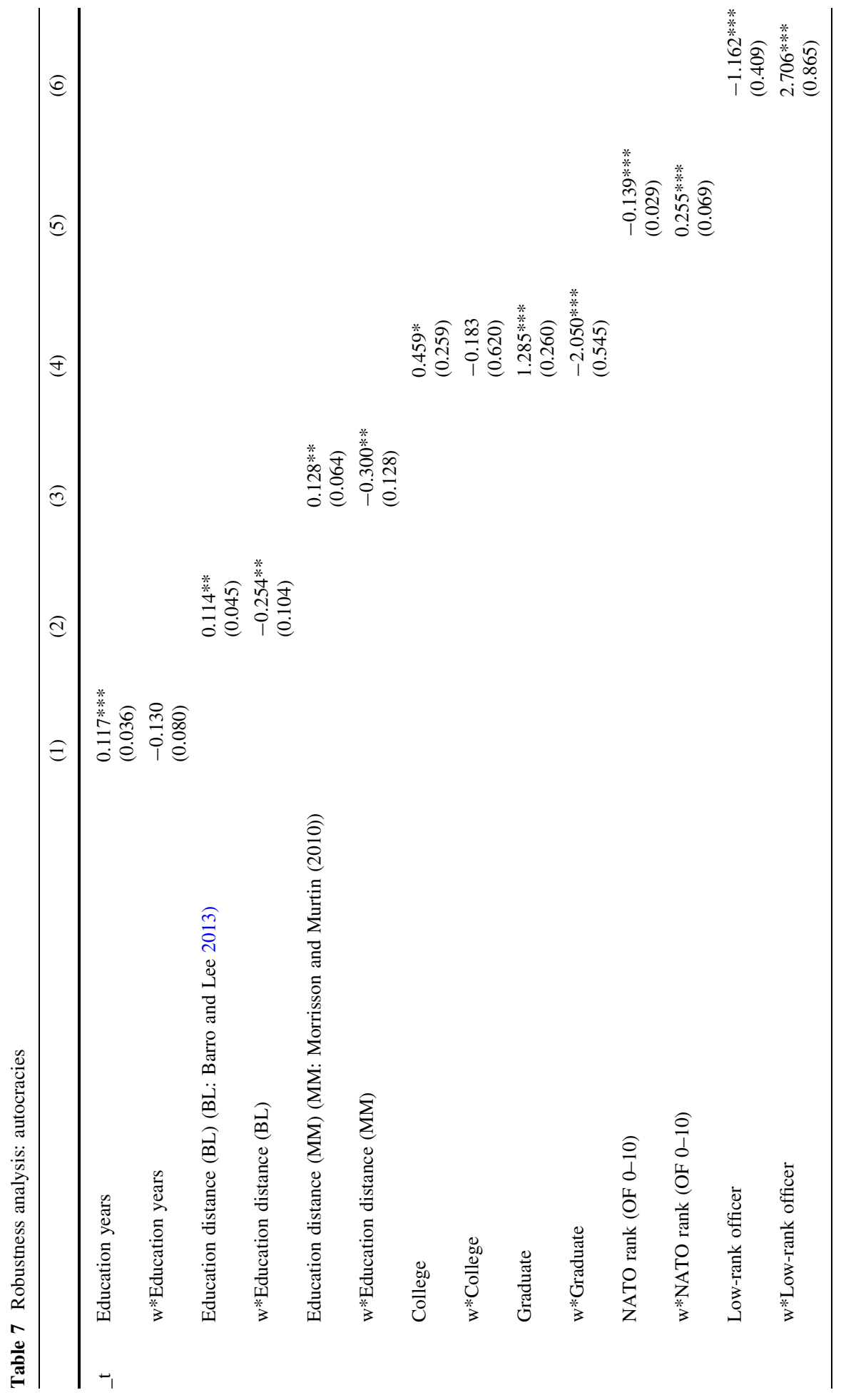




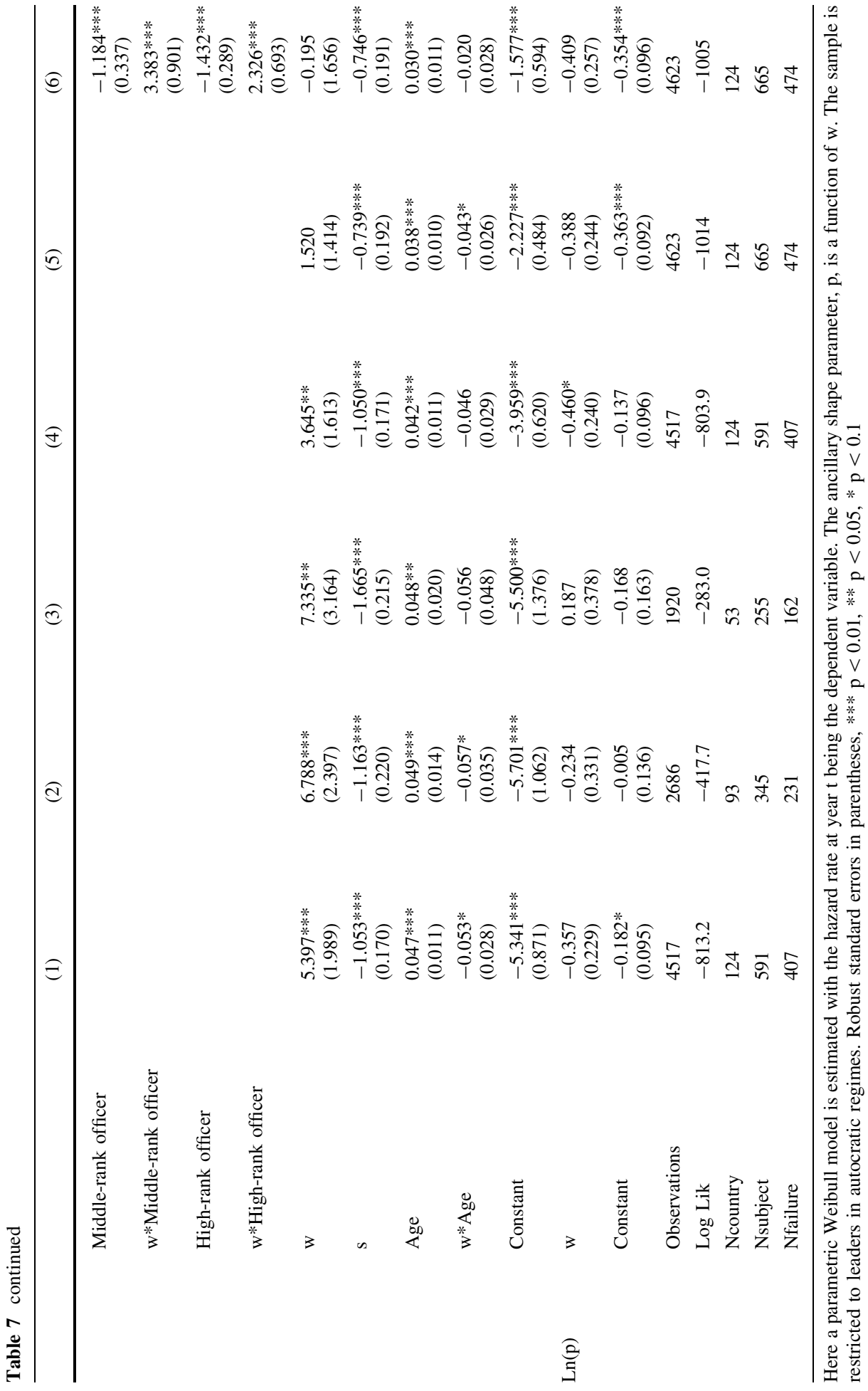


Table 8 Robustness analysis: subsamples

\begin{tabular}{|c|c|c|c|c|c|c|c|}
\hline & & $\begin{array}{l}\text { (1) } \\
\text { Excl. SSA } \\
\text { Rev }\end{array}$ & $\begin{array}{l}\text { (2) } \\
\text { Excl. SSA } \\
\text { Auto }\end{array}$ & $\begin{array}{l}\text { (3) } \\
\text { Excl. } \\
\text { Irregular } \\
\text { Rev }\end{array}$ & $\begin{array}{l}\text { (4) } \\
\text { Excl. } \\
\text { Irregular } \\
\text { Auto }\end{array}$ & $\begin{array}{l}(5) \\
\text { Regular } \\
\text { Only } \\
\text { Rev }\end{array}$ & $\begin{array}{l}\text { (6) } \\
\text { Regular } \\
\text { Only } \\
\text { Auto }\end{array}$ \\
\hline \multirow[t]{9}{*}{$-\mathrm{t}$} & Education4 & $\begin{array}{l}0.448 * * * \\
(0.115)\end{array}$ & $\begin{array}{l}0.850 * * * \\
(0.155)\end{array}$ & $\begin{array}{l}0.360 * * * \\
(0.138)\end{array}$ & $\begin{array}{l}0.688^{* * * *} \\
(0.169)\end{array}$ & $\begin{array}{l}0.330 * * \\
(0.141)\end{array}$ & $\begin{array}{l}0.686 * * * \\
(0.170)\end{array}$ \\
\hline & w*Education 4 & $\begin{array}{l}-0.529 * * * \\
(0.142)\end{array}$ & $\begin{array}{l}-1.197 * * * \\
(0.333)\end{array}$ & $\begin{array}{l}-0.395 * * \\
(0.171)\end{array}$ & $\begin{array}{l}-0.846^{* *} \\
(0.341)\end{array}$ & $\begin{array}{l}-0.366^{* *} \\
(0.174)\end{array}$ & $\begin{array}{l}-0.918^{* * * *} \\
(0.341)\end{array}$ \\
\hline & Military4 & $\begin{array}{l}-0.319 * * * \\
(0.099)\end{array}$ & $\begin{array}{l}-0.249 * * \\
(0.120)\end{array}$ & $\begin{array}{l}-0.298 * * \\
(0.144)\end{array}$ & $\begin{array}{l}-0.087 \\
(0.158)\end{array}$ & $\begin{array}{l}-0.331 * * \\
(0.147)\end{array}$ & $\begin{array}{l}-0.098 \\
(0.160)\end{array}$ \\
\hline & w*Military4 & $\begin{array}{l}0.324^{*} \\
(0.185)\end{array}$ & $\begin{array}{l}0.345 \\
(0.270)\end{array}$ & $\begin{array}{l}0.174 \\
(0.256)\end{array}$ & $\begin{array}{l}-0.054 \\
(0.373)\end{array}$ & $\begin{array}{l}0.212 \\
(0.259)\end{array}$ & $\begin{array}{l}-0.062 \\
(0.380)\end{array}$ \\
\hline & w & $\begin{array}{l}2.692 * * * \\
(0.858)\end{array}$ & $\begin{array}{l}5.853 * * * \\
(1.977)\end{array}$ & $\begin{array}{l}1.742 * \\
(0.977)\end{array}$ & $\begin{array}{l}-0.461 \\
(2.294)\end{array}$ & $\begin{array}{l}1.748 * \\
(0.978)\end{array}$ & $\begin{array}{l}-0.634 \\
(2.351)\end{array}$ \\
\hline & $\mathrm{s}$ & $\begin{array}{l}-0.723 * * * \\
(0.141)\end{array}$ & $\begin{array}{l}-0.908 * * * \\
(0.205)\end{array}$ & $\begin{array}{l}-1.046^{* * * *} \\
(0.187)\end{array}$ & $\begin{array}{l}-1.305^{* * * *} \\
(0.244)\end{array}$ & $\begin{array}{l}-1.030 * * * \\
(0.187)\end{array}$ & $\begin{array}{l}-1.270^{* * * *} \\
(0.249)\end{array}$ \\
\hline & Age & $\begin{array}{l}0.037 * * * \\
(0.009)\end{array}$ & $\begin{array}{l}0.049 * * * \\
(0.013)\end{array}$ & $\begin{array}{l}0.030 * * * \\
(0.010)\end{array}$ & $\begin{array}{l}0.013 \\
(0.016)\end{array}$ & $\begin{array}{l}0.031 * * * \\
(0.010)\end{array}$ & $\begin{array}{l}0.013 \\
(0.016)\end{array}$ \\
\hline & $\mathrm{w}^{*}$ Age & $\begin{array}{l}-0.043^{* * * *} \\
(0.013)\end{array}$ & $\begin{array}{l}-0.087 * * * \\
(0.031)\end{array}$ & $\begin{array}{l}-0.030 * * \\
(0.014)\end{array}$ & $\begin{array}{l}0.017 \\
(0.041)\end{array}$ & $\begin{array}{l}-0.031 * * \\
(0.014)\end{array}$ & $\begin{array}{l}0.020 \\
(0.040)\end{array}$ \\
\hline & Constant & $\begin{array}{l}-2.595 * * * \\
(0.571)\end{array}$ & $\begin{array}{l}-4.214 * * * \\
(0.859)\end{array}$ & $\begin{array}{l}-1.798 * * * \\
(0.657)\end{array}$ & $\begin{array}{l}-1.867 * * \\
(0.940)\end{array}$ & $\begin{array}{l}-1.802 * * * \\
(0.660)\end{array}$ & $\begin{array}{l}-1.826^{*} \\
(0.947)\end{array}$ \\
\hline \multirow[t]{7}{*}{$\operatorname{Ln}(p)$} & W & $\begin{array}{l}0.440 * * \\
(0.183)\end{array}$ & $\begin{array}{l}-0.106 \\
(0.269)\end{array}$ & $\begin{array}{l}0.379 * \\
(0.229)\end{array}$ & $\begin{array}{l}-0.602 \\
(0.521)\end{array}$ & $\begin{array}{l}0.384 * \\
(0.227)\end{array}$ & $\begin{array}{l}-0.560 \\
(0.520)\end{array}$ \\
\hline & Constant & $\begin{array}{l}-0.480 * * * \\
(0.099)\end{array}$ & $\begin{array}{l}-0.284 * * * \\
(0.101)\end{array}$ & $\begin{array}{l}-0.425^{* * * *} \\
(0.128)\end{array}$ & $\begin{array}{l}-0.008 \\
(0.204)\end{array}$ & $\begin{array}{l}-0.430 * * * \\
(0.127)\end{array}$ & $\begin{array}{l}-0.024 \\
(0.203)\end{array}$ \\
\hline & Observations & 3940 & 2904 & 3609 & 2894 & 3555 & 2780 \\
\hline & Log Lik & -1443 & -554.4 & -1264 & -447.8 & -1254 & -434.1 \\
\hline & Ncountry & 116 & 81 & 155 & 119 & 155 & 119 \\
\hline & Nsubject & 1199 & 419 & 1123 & 375 & 1110 & 364 \\
\hline & Nfailure & 828 & 280 & 772 & 270 & 763 & 262 \\
\hline
\end{tabular}

Here a parametric Weibull model is estimated with the hazard rate at year t being the dependent variable. The ancillary shape parameter, $\mathrm{p}$, is a function of $\mathrm{w}$. While columns 1, 3, 5 focus on the sample with revolutionary threats, columns $2,4,6$ focus on regimes under autocratic rulers. In addition, observations from sub-Saharan Africa are removed from the sample in columns 1 and 2. Leaders who reached power by irregular means are dropped in columns 3 and 4 and, furthermore, columns 5 and 6 include observations only on leaders who reached power through regular means Robust standard errors in parentheses, $* * * \mathrm{p}<0.01, * * \mathrm{p}<0.05, * \mathrm{p}<0.1$

power through regular means. ${ }^{34}$ For each subsample, we first focus on the sample with revolutionary threats (columns $1,3,5$ ) and then we focus on regimes under autocratic rulers (columns 2, 4, 6).

Throughout the table, the coefficients for Education 4 and $\mathrm{w}^{*}$ Education 4 consistently have the expected signs and are significant at $5 \%$ level. Moreover, the coefficients for Military4 generally are negative and significant. Although the coefficients for $\mathrm{w}^{*}$ Military

\footnotetext{
34 The information on leaders' entry modes are obtained from Archigos 2.9, where entry modes are categorized into three types, i.e., through regular means, irregular means, and foreign intervention. Entry by regular means represents leaders who are selected into political office in a manner prescribed by either explicit rules or established conventions. If the leader is not directly imposed by a foreign state, then he reaches office by irregular means, which include, for example, coup d'états and civil wars.
} 
Table 9 Summary of statistics

\begin{tabular}{|c|c|c|c|c|c|c|c|}
\hline Variable & Definition & Source & Obs & Mean & SD & Min & Max \\
\hline Eduction4 & $\begin{array}{l}\text { Education attainment of the } \\
\text { incumbent before office }\end{array}$ & Various sources & 11,197 & 1.05 & 0.97 & 0 & 3 \\
\hline Military4 & $\begin{array}{c}\text { The highest military rank } \\
\text { achieved before office }\end{array}$ & Various sources & 12,032 & 0.67 & 1.11 & 0 & 3 \\
\hline w & $\begin{array}{l}\text { The size of the winning } \\
\text { coalition }\end{array}$ & $\begin{array}{l}\text { Bueno de } \\
\text { Mesquita and } \\
\text { Smith (2010) }\end{array}$ & 12,097 & 0.58 & 0.3 & 0 & 1 \\
\hline s & The size of the selectorate & $\begin{array}{l}\text { Bueno de } \\
\text { Mesquita and } \\
\text { Smith (2010) }\end{array}$ & 12,097 & 0.86 & 0.33 & 0 & 1 \\
\hline Age & The age of the incumbent & $\begin{array}{c}\text { Archigos } \\
(2009)\end{array}$ & 12,097 & 55.47 & 11.72 & 15 & 93 \\
\hline $\operatorname{Ln}(\mathrm{GDPpc})$ & $\begin{array}{l}\text { GDP per capita in natural } \\
\text { logarithms }\end{array}$ & $\begin{array}{l}\text { World } \\
\text { Development } \\
\text { Indicator } \\
(2014)\end{array}$ & 5956 & 7.41 & 1.54 & 4.28 & 10.91 \\
\hline Growth & Annual GDP growth rate & $\begin{array}{l}\text { World } \\
\text { Development } \\
\text { Indicator } \\
(2014)\end{array}$ & 5931 & 3.65 & 6.34 & -50.25 & 106.28 \\
\hline Mass & $\begin{array}{l}\text { A measure of revolutionary } \\
\text { threats based on the } \\
\text { occurrence of mass } \\
\text { political movements. }\end{array}$ & $\begin{array}{l}\text { Bueno de } \\
\text { Mesquita and } \\
\text { Smith (2010) }\end{array}$ & 9196 & 0.08 & 0.75 & -0.37 & 4.66 \\
\hline Mass & $\begin{array}{l}\text { The change in the level of } \\
\text { mass over the previous } \\
3 \text { years, i.e. Mass }- \text { Mass }_{\mathrm{t}-3}\end{array}$ & $\begin{array}{l}\text { Bueno de } \\
\text { Mesquita and } \\
\text { Smith (2010) }\end{array}$ & 8437 & 0.01 & 0.81 & -3.99 & 4.32 \\
\hline $\begin{array}{l}\text { Education } \\
\text { years }\end{array}$ & $\begin{array}{l}\text { The numbers of years the } \\
\text { incumbent spent on } \\
\text { education }\end{array}$ & Various sources & 11,197 & 14.31 & 4.95 & 0 & 20 \\
\hline $\begin{array}{l}\text { Education } \\
\text { distance } \\
\text { (BL) }\end{array}$ & $\begin{array}{l}\text { The numbers of years the } \\
\text { incumbent spent on } \\
\text { education relative to that } \\
\text { of the average citizen of } \\
\text { the country }\end{array}$ & $\begin{array}{l}\text { Barro and Lee } \\
\text { (2013) }\end{array}$ & 4918 & 11.67 & 4.45 & -5.18 & 20 \\
\hline $\begin{array}{l}\text { Education } \\
\text { distance } \\
(\mathrm{MM})\end{array}$ & $\begin{array}{l}\text { The numbers of years the } \\
\text { incumbent spent on } \\
\text { education relative to that } \\
\text { of the average citizen of } \\
\text { the country }\end{array}$ & $\begin{array}{l}\text { Morrisson and } \\
\text { Murtin (2012) }\end{array}$ & 6532 & 10.46 & 4.92 & -6.76 & 19.72 \\
\hline $\begin{array}{l}\text { NATO } \\
\text { rank (OF } \\
0-10)\end{array}$ & $\begin{array}{l}\text { The highest military rank } \\
\text { achieved before office } \\
\text { (NATO-system) }\end{array}$ & Various sources & 12,032 & 1.89 & 3.51 & 0 & 10 \\
\hline College & $\begin{array}{l}\text { A dummy variable, which } \\
\text { equals } 1 \text { if the incumbent } \\
\text { has a college degree or } \\
\text { above and } 0 \text { otherwise }\end{array}$ & Various sources & 14,379 & 0.65 & 0.48 & 0 & 1 \\
\hline Graduate & $\begin{array}{l}\text { A dummy variable, which } \\
\text { equals } 1 \text { if the incumbent } \\
\text { has a master degree or } \\
\text { above and } 0 \text { otherwise }\end{array}$ & Various sources & 14,379 & 0.27 & 0.44 & 0 & 1 \\
\hline
\end{tabular}


are less significant in the subsamples, the coefficients are positive when leaders face a revolutionary threat. Therefore, we confirm that our main results are not driven by African leaders or by leaders who came into office through irregular means, such as coup d'états.

\section{Conclusion}

The literature on political survival has shown that many features of the political, economic, and institutional landscape influence the survival of political leaders. In this paper we show that the survival of political leaders also depends on the leader himself (or herself). We have extended the selectorate theory of Bueno de Mesquita et al. (2003) by allowing for heterogeneous political leaders. By focusing on the motives of the winning coalition, we have derived the proposition that, under a revolutionary threat, economic competence can be detrimental to political survival, but that the effect is moderated by the size of the winning coalition. As the winning coalition grows, the negative effect of economic competence on political survival falls. On the other hand, military competence can increase the chance of political survival. However, again, the effect depends on the size of the winning coalition. Military competence of the political leader is important when the winning coalition is small, as the members obtain considerable private rents and, hence, care about maintaining their position in the winning coalition.

Our empirical results confirm the predictions of our model. We conclude that in order to understand political survival of leaders it is not sufficient to look at only the economic, political, and institutional context. The personal characteristics of political leaders also are important determinants that contribute to the understanding of political survival. Most interestingly, our results suggest that these personal characteristics interact with the institutional context and that a leader with certain characteristics is more able to survive in one context or another.

Naturally, our study has its limitations. For instance, our model assumes that the country under investigation suffers from a revolutionary threat. This implies that the model is representative only of a subset of all countries and that it does not apply to stable democracies. For stable democracies, one could argue that military competence is less relevant and that other forms of competence play a role in securing the support of the winning coalition. One could think of political competence, e.g., how well a politician can run a political campaign or how well he is able to manage a (coalition) government. Another limitation relates to the measurement of our competence variables, especially military competence. Using military ranks, based on the NATO classification system, is a crude way of proxying the latent concept of military competence. It may well be that in autocracies higher military ranks simply reflect the fact that someone belongs to the right network (which is analogous to the argument respecting political competence in democracies). It may also well be that noncommissioned officers with battlefield experience (e.g., sergeants) outperform commissioned officers that received mainly academic training. We believe, however, that such cases are rare and that our approach is a feasible way of making comparative analysis possible. Of course, reflecting on empirical results that we would have obtained when better proxies would have been available is highly speculative. Improving upon measurement issues and developing a framework that also is able to understand political survival in stable democracies sets a natural agenda for further research.

Acknowledgments We are grateful to Arnold Ludwig and Gregory Gunthner for making the data set used in Ludwig (2002) available to us. For useful comments and discussions, we are grateful to Jakob de Haan, 
Alistair Smith, Hein Goemans, Pim Heijnen, James Vreeland, Atin Basu Choudhary, Matteo Cervellati, Marco Haan and the participants at the Ifo Lunchtime Seminar, the EPCS Meeting in Zuerich, The Public Choice Meeting in San Antonio, Texas, the Nederlandse Economendag, Fudan University, Remin University, Virginia Military Institute, University of Rochester and the PEG\&DEcH Seminar in University of Groningen.

Open Access This article is distributed under the terms of the Creative Commons Attribution 4.0 International License (http://creativecommons.org/licenses/by/4.0/), which permits unrestricted use, distribution, and reproduction in any medium, provided you give appropriate credit to the original author(s) and the source, provide a link to the Creative Commons license, and indicate if changes were made.

\section{References}

Acemoglu, D., Egorov, G., \& Sonin, K. (2008). Coalition formation in nondemocratic societies. Review of Economic Studies, 75, 987-1009.

Acemoglu, D., \& Robinson, J. (2006). Economic origins of dictatorship and democracy. Cambridge: Cambridge University Press.

Banks, A. S., \& Wilson, K. A. (2007). Cross-national time-series data archive user's manual. Jerusalem, Israel: Databanks International.

Barro, R., \& Lee, J. W. (2013). A new data set of educational attainment in the world, 1950-2010. Journal of Development Economics, 104, 184-198.

Besley, T., Montalvo, J., \& Reynal-Querol, M. (2011). Do educated leaders matter? The Economic Journal, 121, 205-227.

Besley, T., \& Reynal-Querol, M. (2011). Do democracies select more educated leaders? American Political Science Review, 105(03), 552-566.

Bueno de Mesquita, B., \& Siverson, R. (1995). War and the survival of political leaders: A comparative study of regime types and political accountability. American Political Science Review, 89(4), 841-855.

Bueno de Mesquita, B., \& Smith, A. (2009). Political survival and endogenous institutional change. Comparative Political Studies, 42(2), 167-197.

Bueno de Mesquita, B., \& Smith, A. (2010). Leader survival, revolutions, and the nature of government finance. American Journal of Political Science, 54(4), 936-950.

Bueno de Mesquita, B., Smith, A., Siverson, A., \& Morrow, J. (2003). The logic of political survival. Cambridge, MA: MIT Press.

Bueno de Mesquita, B., Smith, A., Siverson, A., \& Morrow, J. (2008). Retesting selectorate theory: Separating the effects of w from other elements of democracy. American Political Science Review, 102(3), 393-400.

Cheibub, J. A., Gandhi, J., \& Vreeland, J. (2010). Democracy and dictatorship revisited. Public Choice, 143, 67-101.

Clarke, K. A., \& Stone, R. (2008). Democracy and the logic of political survival. American Political Science Review, 102, 387-392.

Cuaresma, J. C., Oberhofer, R., \& Raschky, P. A. (2011). Oil and the duration of dictatorships. Public Choice, 148, 505-530.

Goemans, H. E., Gleditsch, K. S., \& Chiozza, G. (2009). Introducing archigos: A dataset of political leaders. Journal of Peace Research, 46(2), 269-283.

Holcombe, R. G., \& Boudreaux, C. J. (2013). Institutional quality and the tenure of autocrats. Public Choice, 156, 409-421.

Konishi, H., \& Ray, D. (2003). Coalition formation as a dynamic process. Journal of Economic Theory, 110, $1-41$.

Ludwig, A. M. (2002). King of the mountain: The nature of political leadership. Lexington, KY: University Press of Kentucky.

Morrisson, C., \& Murtin, F. (2012). The kuznets curve of human capital inequality, 1870 to 2010. The Journal of Economic Inequality, 11, 1-19.

Przeworski, A., \& Gandhi, J. (2007). Authoritarian institutions and the survival of autocrats. Comparative Political Studies, 40, 12-79.

Ray, D., \& Vohra, R. (1999). A theory of endogenous coalition structures. Games and Economic Behavior, $26,286-336$. 